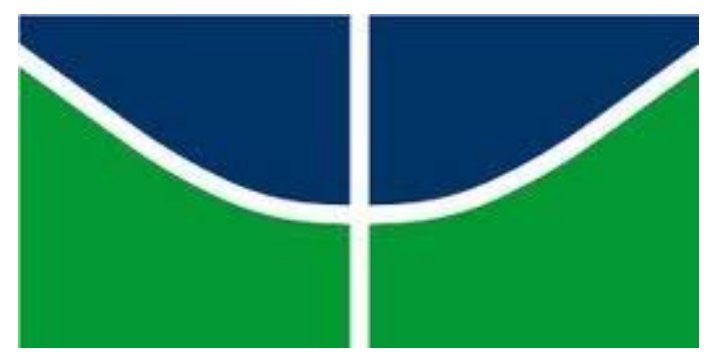

UNIVERSIDADE DE BRASÍLIA

JOSEILMA LUCIANA NEVES SIQUEIRA

ALTERAÇÕES ESTRUTURAIS E METABÓLICAS INDUZIDAS POR CITRATO EM CÉLULAS TUMORAIS (MCF-7) E NÃO TUMORAIS (FIBROBLASTOS) IN VITRO

BRASÍLIA

2016 
JOSEILMA LUCIANA NEVES SIQUEIRA

ALTERAÇÕES ESTRUTURAIS E METABÓLICAS INDUZIDAS POR CITRATO EM CÉLULAS TUMORAIS (MCF-7) E NÃO TUMORAIS (FIBROBLASTOS) IN VITRO

Dissertação apresentada ao Programa de Pós-Graduação em Biologia Animal, do Instituto de Ciências Biológicas, da Universidade de Brasília - UnB, como parte dos requisitos para obtenção do título de Mestre em Biologia Animal.

Orientadora: Profa. Dra. Sônia Nair Báo

BRASÍLIA

2016 


\title{
ALTERAÇÕES ESTRUTURAIS E METABÓLICAS INDUZIDAS POR CITRATO EM CÉLULAS TUMORAIS (MCF-7) E NÃO TUMORAIS (FIBROBLASTOS) IN VITRO
}

\begin{abstract}
Dissertação apresentada ao Programa de Pós-Graduação em Biologia Animal, do Instituto de Ciências Biológicas, da Universidade de Brasília - UnB, como parte dos requisitos para obtenção do título de Mestre em Biologia Animal.
\end{abstract}

Aprovado em: 20 / 07 / 2016

\section{COMISSÃO EXAMINADORA}

Profa. Dra. Sônia Nair Báo (UnB) (Presidente)

Profa. Dra. Zulmira Guerrero Lacava (UnB) (Membro titular)

Profa. Dra. Ana Luísa Miranda-Vilela (Faciplac)

(Membro titular)

Prof. Dr. João Paulo Figueiró Longo (UnB)

(Membro suplente) 
À minha mãe, por sonhar o meu sonho. 


\section{Agradecimentos}

À Deus, pelas oportunidades e pelos desafios de cada dia.

Aos meus pais, Maria Neves e Josemir Siqueira, por todos os sacrifícios realizados e que me permitiram alcançar mais essa etapa da minha vida.

À minha amiga-irmã, Dilmara Coelho, que sempre torceu pelo meu sucesso.

À Profa. Sônia Báo, que me deu a oportunidade que eu precisava para trilhar a minha trajetória acadêmica. Agradeço a confiança depositada.

À Profa. Marcella Carneiro, pelas contribuições na elaboração do meu projeto.

Ao Christiano Gati, por ter sido o tutor que eu desejei encontrar na minha trajetória acadêmica.

Aos amigos Cláudio Lopes, pelas análises de morfometria; Natália Lemos, pelo suporte nas análises de citometria; Daniela Carrilho e Lorena Andrade, pelas contribuições para os ensaios de microscopia confocal.

Aos colegas dos Laboratórios de Microscopia Eletrônica, Virologia e Enzimologia e do Departamento de Genética e Morfologia, que compartilharam seus conhecimentos, experiências e materiais. Meus agradecimentos à Márcia Rocha, Karine Barros, Ingrid Silva, Shaiane Crossetti, Brígida Alves, Misléia Rodrigues, Yasmin Andrade, Ana Luisa Gouveia, Núbia Sousa, Bruna Guido, Fabrício Morgado, Caio Gorgulho, Helder Gomes, Daniel Araújo, Leonardo Silva, Brenda Camargo, Rayane Ganassin e Luíza.

Ao Prof. Bergmann Ribeiro, pelo acesso ao seu laboratório, onde desenvolvi parte dos meus experimentos.

Às amigas Mayara Santos, Daniela Carrilho e Katiúscia Jardim, com quem pude compartilhar minhas angústias nos momentos de frustrações.

À dona Neíta Moura, pelos cuidados dispensados nos tempos em que eu não tinha tempo para cuidar de nada.

Ao Programa de Pós-Graduação em Biologia Animal, por meio do qual desenvolvi o meu mestrado.

Às agências de fomento CNPq, FAPDF, FINEP e CAPES, pelo financiamento. Minha gratidão a todos! 


\section{Resumo}

O citrato é um metabólito intermediário do ciclo de Krebs que possui função alostérica. Quando em altas concentrações, esta molécula modula a glicólise por meio da inibição da atividade da enzima fosfofrutoquinase no citoplasma. As células de câncer apresentam reprogramação do seu metabolismo energético, produzindo energia, preferencialmente, por via glicolítica. Esta estratégia pode ser consequência de privação de oxigênio no microambiente do tumor; da rápida obtenção de energia, quando comparada à fosforilação oxidativa; de disfunção mitocondrial; ou mesmo da manutenção da homeostase mitocondrial, preservando a organela de estresse oxidativo. Nesse sentido, o citrato pode ser explorado como potencial agente antitumoral, atuando em processos-chave do funcionamento das células neoplásicas. O objetivo deste trabalho foi investigar alterações estruturais e metabólicas induzidas por citrato em células da linhagem tumoral MCF-7 (adenocarcinoma mamário humano) e em células normais (cultura primária de fibroblastos derivados de polpa dentária humana). Ensaios de citotoxicidade por meio do método colorimétrico MTT demonstraram redução da viabilidade dos dois tipos celulares de maneira dependente do tempo e da concentração do tratamento. O citrato foi mais citotóxico em células MCF-7 do que em fibroblastos na concentração de $20 \mathrm{mM}$ e nos tempos de 24 e $48 \mathrm{~h}$. $O$ teor de citrato nas células MCF-7 é elevado no grupo controle e o tratamento não reduziu a produção de lactato. Foi observado inibição da atividade da enzima fosfofrutoquinase das células MCF-7 tratadas com citrato. Análises morfométricas apontaram alterações ultraestruturais das mitocôndrias em fibroblastos, o que sugere adaptação ao estresse celular produzido pelo tratamento. Não foi observado alteração de potencial de membrana mitocondrial em ambas as células após tratamento. No entanto, MCF7 apresentou formação de espécies reativas de oxigênio.

Palavras-chave: citrato, câncer de mama, metabolismo energético, mitocôndrias. 


\section{Abstract}

Citrate is an intermediate metabolite in the Krebs cycle that has allosteric function. When this molecule is present in high concentrations, it modulates the glycolysis through inhibition of the enzyme phosphofructokinase activity in the cytoplasm. Cancer cells exhibit metabolic reprogramming to the energy production preferably by glycolytic pathway. This strategy may result from oxygen deprivation in the tumor microenvironment; the rapid achievement of energy compared to oxidative phosphorylation; mitochondrial dysfunction; or even the maintenance of mitochondrial homeostasis, preserving organelle against oxidative stress. Therefore, the citrate can be explored as a potential antitumor agent, working in the key processes of cellular functions of the cancer cells. The objective of this study was to investigate structural and metabolic changes induced by citrate in tumor cell line MCF-7 (human breast adenocarcinoma) and normal cells (primary culture of human dental pulp-derived fibroblasts). Cytotoxicity assays using the MTT colorimetric method performed in three independent experiments, demonstrated that citrate reduced the viability of both cell types in a manner dependent on the time and concentration of the treatment. Citrate was more cytotoxic in MCF-7 cells than in fibroblasts in a concentration of $20 \mathrm{mM}$ at 24 and $48 \mathrm{~h}$. The citrate content in MCF-7 cells is elevated in the control group and the treatment didn't reduce the production of lactate. Morphometric analysis showed ultrastructural changes of mitochondria in fibroblasts. These changes suggest adaptation to cellular stress produced by the treatment. There was no alteration in mitochondrial membrane potential in both cells after treatment. However, MCF-7 showed formation of reactive oxygen species.

Keywords: citrate, breast cancer, energy metabolism, mitochondria. 


\section{Lista de figuras}

Figura 1 - llustração do tecido normal da mama feminina.......................................15

Figura 2 - Representação esquemática da fermentação láctica.............................16

Figura 3 - Resumo do metabolismo da glicose..................................................18

Figura 4 - Representação esquemática do transporte de citrato na célula...............19

Figura 5 - Dinâmica mitocondrial..................................................................29

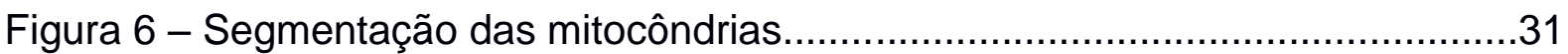

Figura 7 - Efeito do citrato na viabilidade celular após tratamento por 24 e 48 h.....36

Figura 8 - Morfologia celular após tratamento com diferentes doses de citrato........37

Figura 9 - Micrografias eletrônicas de células controle e tratadas com citrato...........38

Figura 10 - Área mitocondrial média..............................................................39

Figura 11 - Razão de aspecto das mitocôndrias....................................................39

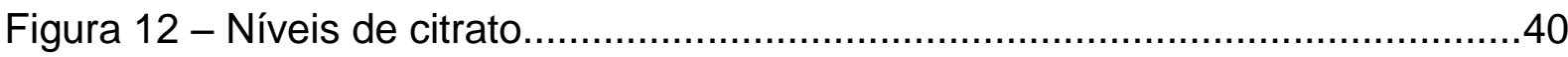

Figura 13 - Conteúdo de piruvato ..........................................................................

Figura 14 - Atividade da enzima fosfofrutoquinase ............................................42

Figura 15 - Teor de lactato em MCF-7 ............................................................

Figura 16 - Produção de espécies reativas de oxigênio...........................................43

Figura 17 - Potencial de membrana mitocondrial...............................................44 


\section{Lista de tabelas}

Tabela 1 - Concentração inibitória de $50 \%$ das células com intervalo de confiança de

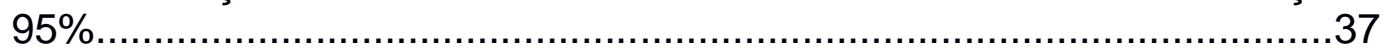




\section{Lista de abreviaturas e siglas}

4T1 Carcinoma mamário murino

ACLy ATP citrato liase

ACS

American Cancer Society

ADP

Adenosina difosfato

AMP

Adenosina monofosfato

APAF-1 Fator de ativação de protease apoptótica 1

ATC

Ciclo do ácido tricarboxílico

ATP

Adenosina trifosfato

$\mathrm{Cl}_{50 \%}$

Concentração inibitória de $50 \%$ das células

$\mathrm{CIC}$

Transportador de citrato mitocondrial

DAPI

Dihidrocloridrato de 4',6-diamidino-2-fenilindol

DCFH-DA

2,7-diacetato de diclorofluoresceína

DMEM

Dulbecco's Modified Eagle's Medium

DMSO

Dimetilsulfóxido

ERO

Espécies reativas de oxigênio

EUA

Estados Unidos da América

$\mathrm{FAD}^{+}$

Flavina-adenina dinucleotídeo

$\mathrm{FADH}_{2}$

Flavina-adenina dinucleotídeo reduzido

GDP

Guanosina difosfato

GLUT-1

Transportador de glicose tipo 1

GLUT-12

Transportador de glicose tipo 12

GTP

Guanosina trifosfato

HS-CoA

Coenzima A

HSF-1

Fator de transcrição de choque térmico

IBGE

Instituto Brasileiro de Geografia e Estatística

INCA

Instituto Nacional do Câncer

LDH-A

Lactato desidrogenase $A$

LDH-B

Lactato desidrogenase $B$

MCF-10A Linhagem de células epiteliais da mama humana

MCF-7

Linhagem de células de adenocarcinoma mamário humano

MCT4

Transportador de monocarboxilatos 4

MDA-MB-231

Carcinoma mamário humano 


$\begin{array}{ll}\text { MET } & \text { Microscópio eletrônico de transmissão } \\ \text { MTORC1 } & \text { Complexo 1 do alvo da rapamicina em mamíferos } \\ \text { MTT } & \text { brometo de 3-[4,5-dimetil-tiazol-2-il]-2,5-difeniltetrazólio } \\ \text { NAD }^{+} & \text {Nicotinamida adenina dinucleotídeo } \\ \text { NADH } & \text { Nicotinamida adenina dinucleotídeo reduzido } \\ \text { OAA } & \text { Oxaloacetato } \\ \text { PBS } & \text { Tampão fosfato salina } \\ \text { PFK } & \text { Fosfofrutoquinase } \\ \text { PI3K } & \text { Fosfatidilinositol 3-quinase } \\ \text { PTC } & \text { Proteína transportadora de citrato } \\ \text { SFB } & \text { Soro fetal bovino } \\ \text { SKBR3 } & \text { Adenocarcinoma de mama humano } \\ \text { TCMP } & \text { Transportador de citrato na membrana plasmática } \\ \text { VEGF } & \text { Fator de crescimento endotelial vascular } \\ \text { WHO } & \text { World Health Organization }\end{array}$




\section{Lista de símbolos}

\begin{tabular}{|c|c|}
\hline$\%$ & Porcentagem \\
\hline \pm & Mais ou menos \\
\hline$\mu \mathrm{L}$ & Microlitros \\
\hline$\mu \mathrm{M}$ & Micromolar \\
\hline$\mu m^{2}$ & Micrômetros quadrados \\
\hline $\mathrm{cm}^{2}$ & Centímetros quadrados \\
\hline $\mathrm{CO}_{2}$ & Gás carbônico \\
\hline$e^{-}$ & Elétron \\
\hline$g / L$ & Gramas por litro \\
\hline $\mathrm{h}$ & Horas \\
\hline $\mathrm{H}^{+}$ & ĺon hidrogênio \\
\hline $\mathrm{H}_{2} \mathrm{O}$ & Água \\
\hline $\mathrm{H}_{2} \mathrm{O}_{2}$ & Peróxido de hidrogênio \\
\hline $\mathrm{kDa}$ & KiloDaltons \\
\hline $\mathrm{L}$ & Litros \\
\hline M & Molar \\
\hline $\mathrm{mL}$ & Mililitros \\
\hline $\mathrm{mM}$ & Milimolar \\
\hline $\mathrm{Na}^{+}$ & ĺon sódio \\
\hline ng & Nanogramas \\
\hline $\mathrm{nm}$ & Nanômetros \\
\hline $\mathrm{nmol}$ & Nanomolar \\
\hline $\mathrm{O}_{2}$ & Gás oxigênio \\
\hline$\stackrel{\circ}{C}$ & Graus Celsius \\
\hline $\mathrm{p}$ & Probabilidade de significância \\
\hline $\mathrm{pH}$ & Potencial hidrogeniônico \\
\hline $\mathrm{Pi}$ & Fosfato inorgânico \\
\hline $\mathrm{R}^{2}$ & Coeficiente de determinação \\
\hline $\mathrm{v} / \mathrm{v}$ & Volume por volume \\
\hline$\times g$ & Força centrífuga relativa \\
\hline$\Delta \Psi$ & Potencial de membrana mitocondrial \\
\hline$\lambda$ & Comprimento de onda \\
\hline
\end{tabular}




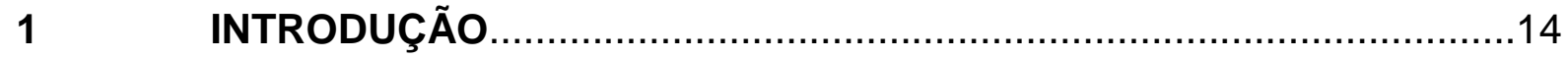

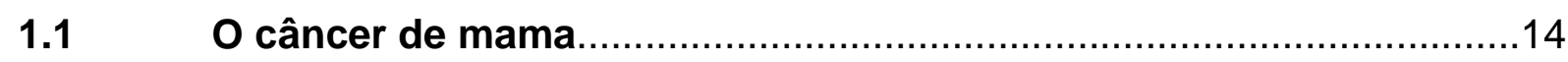

1.2 Aspectos do metabolismo energético de células neoplásicas..........16

1.3 Citrato e câncer......................................................................23

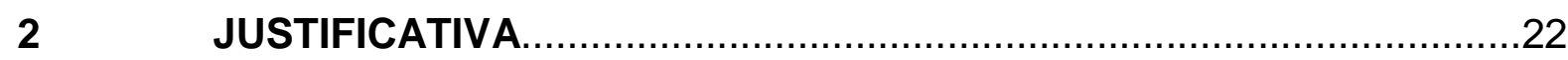

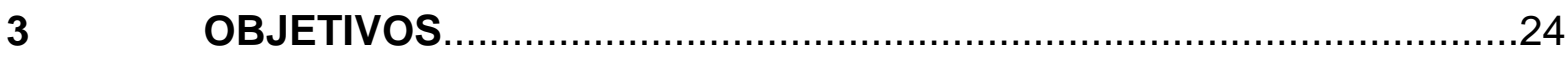

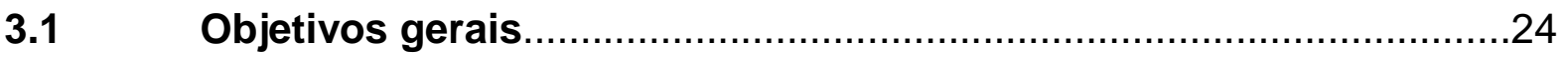

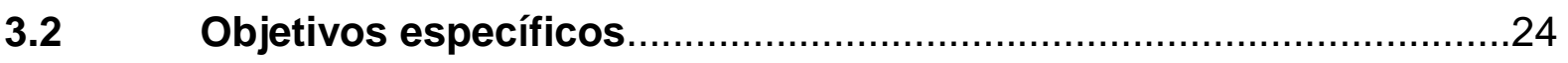

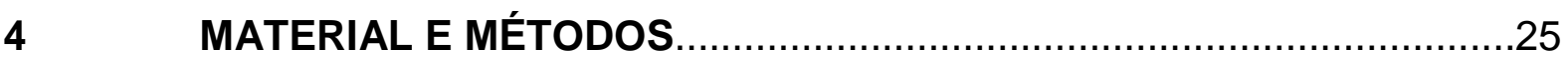

4.1 Materiais, reagentes e equipamentos........................................

4.2 Cultura e manutenção das células...........................................27

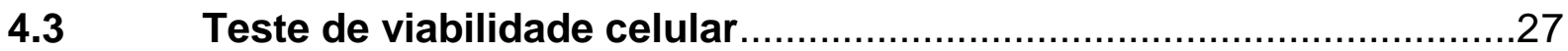

4.4 Alterações morfológicas e ultraestruturais....................................29

4.4.1 Análise por microscopia eletrônica de transmissão.............................29

4.4.2 Morfometria de mitocôndrias..........................................................30

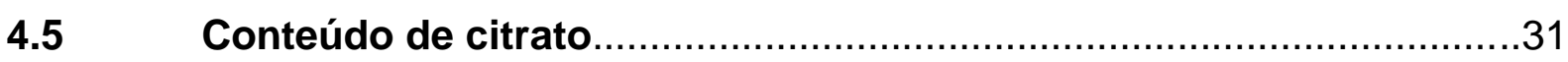

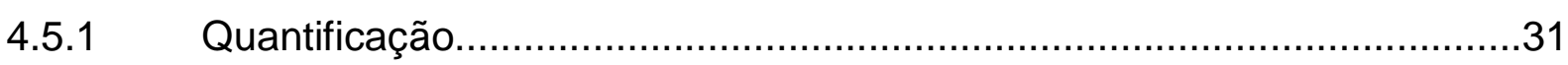

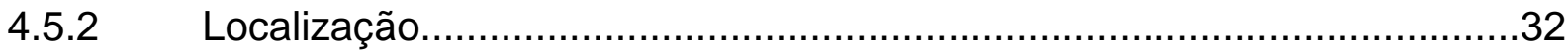

4.6 Inibição da glicólise via enzima fosfofrutoquinase .........................33

4.6.1 Inibição da atividade da enzima fosfofrutoquinase ................................33

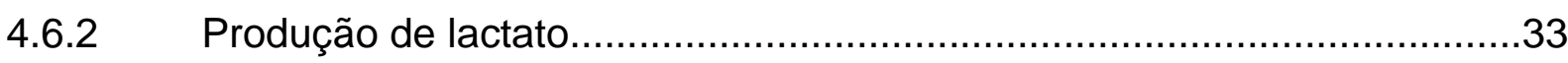

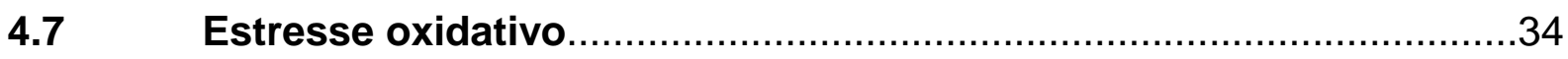

4.7.1 Formação de espécies reativas de oxigênio intracelulares.....................34

4.7.2 Alteração de potencial de membrana mitocondrial.................................35

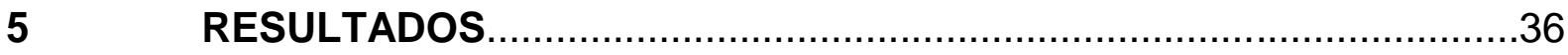

5.1 Citotoxicidade do citrato em fibroblastos e MCF-7 ........................36

5.2 Alterações morfológicas e ultraestruturais induzidas por citrato......37

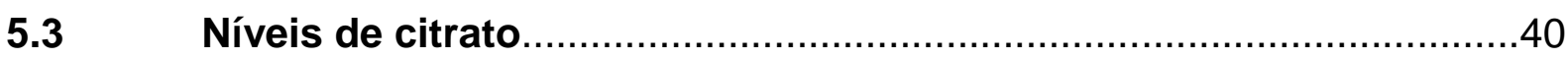

$5.4 \quad$ Atividade da enzima fosfofrutoquinase ......................................42

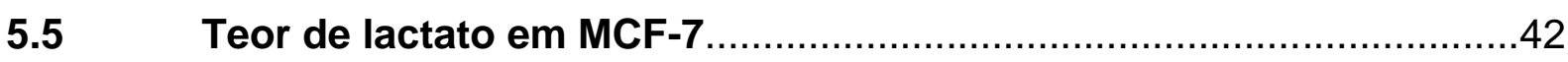

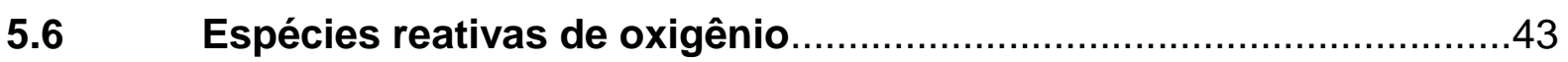

5.7 Potencial de membrana mitocondrial.........................................43 
DISCUSSÃO. 


\section{INTRODUÇÃo}

\subsection{O Câncer de mama}

O câncer é uma doença que acomete pessoas em todo o mundo. É a segunda causa de mortalidade, sendo superada somente pelas doenças cardiovasculares. O câncer de mama é o mais incidente em mulheres entre todos os cânceres, excluindo o de pele não melanoma. Em 2015, houve aproximadamente 1,8 milhão de novos casos estimados da doença no mundo e constituiu a principal causa de morte de mulheres por câncer (WHO, 2016).

Estima-se que em 2016 surjam 57.960 novos casos no Brasil, representando 28,1\% dos cânceres incidentes (INCA, 2016). Entre 2004 e 2013, o número de óbitos de mulheres por esta neoplasia aumentou $45 \%$ no país (INCA, 2014).

O desenvolvimento do câncer é um processo de múltiplas etapas que envolve a capacidade de células normais em adquirir, progressivamente, propriedades tumorigênicas, que podem levar, em última instância, à malignidade. A biologia do câncer apresenta como características a manutenção da sinalização proliferativa, a perda de função dos genes supressores de crescimento, a resistência a apoptose, a aptidão para a imortalidade replicativa, a indução da angiogênese, a ativação da invasão de tecidos adjacentes e metástase, a instabilidade genética e mutação, a reprogramação do metabolismo energético e a fuga da destruição imunológica (HANAHAN \& WEINBERG, 2011).

Os tumores de mama são classificados pela Organização Mundial da Saúde segundo critérios histopatológicos que consideram recentes avanços nos conhecimentos sobre dados genéticos e moleculares. Entre os tumores epiteliais, são descritos nove tipos de carcinomas invasivos e seus subtipos, carcinomas invasivos de nenhum tipo especial e onze tipos raros de carcinomas invasivos. Incluem-se, ainda, na classificação, tumores mioepiteliais-epiteliais, tumores mesenquimais, lesões precursoras, lesões proliferativas intraductais, lesões papilares e proliferações epiteliais benignas (LAKHANI et al, 2012; SINN \& KREIPE, 2013).

O risco de desenvolver câncer aumenta com o envelhecimento. É encontrado cerca de 1 em 8 cânceres de mama invasivos em mulheres com idade 
inferior a 45 anos, enquanto são encontrados cerca de 2 em 3 cânceres de mama invasivos em mulheres com idade superior a 55 anos (ACS, 2015).

As principais intervenções terapêuticas empregadas em todo o mundo no tratamento de câncer são a cirurgia, a radioterapia, a quimioterapia, a hormonoterapia ou a combinação delas (WHO, 2008). A imunoterapia, ainda, compreende uma modalidade emergente no tratamento do câncer, com 0 desenvolvimento de vacinas contra antígenos associados ao tumor (MELERO et al, 2014; KRANZ et al, 2016).

Para detecção precoce e diagnóstico do câncer de mama, o Ministério da Saúde orienta o exame clínico anual das mamas (Figura 1) a partir dos 40 anos de idade e um exame mamográfico a cada dois anos para mulheres de 50 a 69 anos (INCA, 2004). No entanto, o levantamento realizado pelo Instituto Brasileiro de Geografia e Estatística (IBGE), em 2008, das condições de acesso e utilização de serviços de saúde no Brasil mostrou que $28,9 \%$ das mulheres nesta faixa etária nunca realizaram a mamografia (IBGE, 2010).

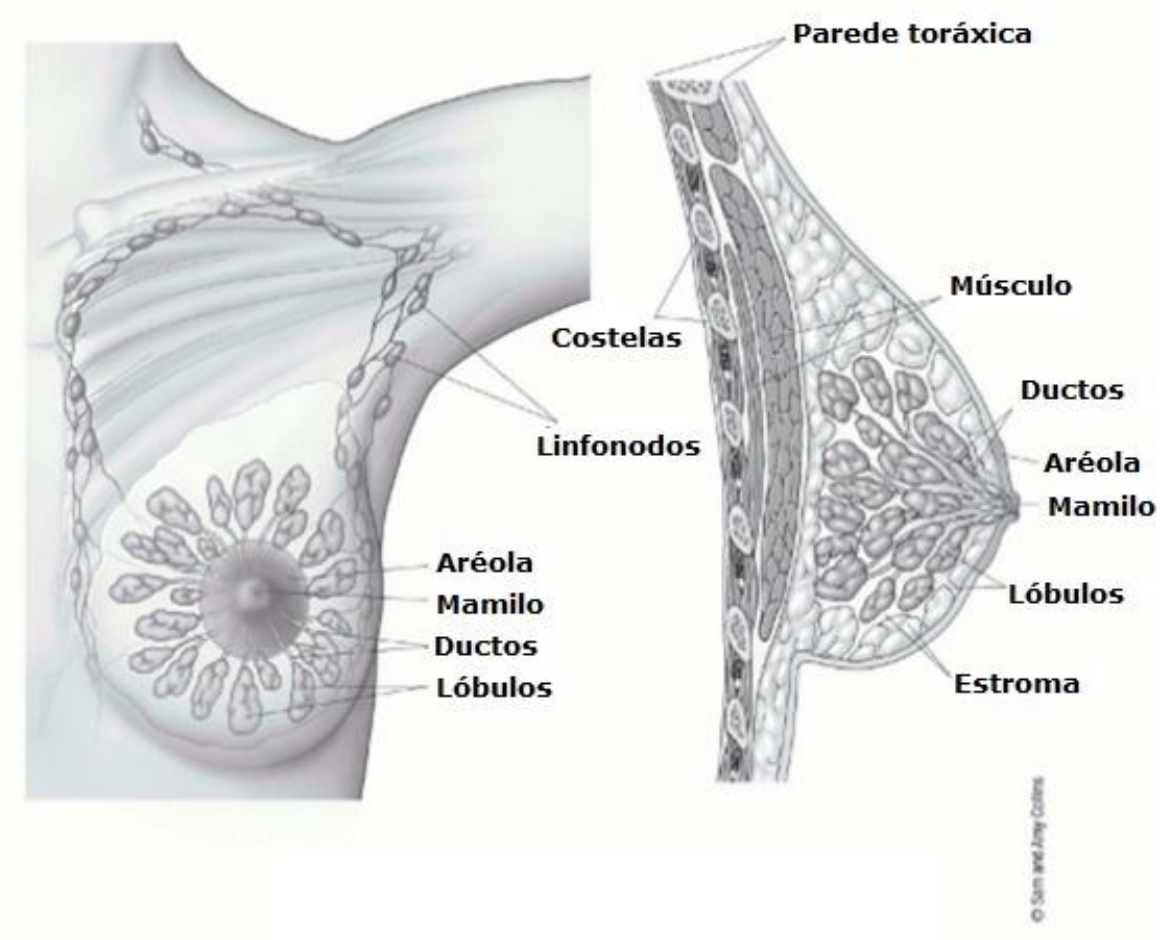

Figura 1. llustração do tecido normal da mama feminina. A mama é constituída principalmente por lóbulos, ductos e estroma. A maioria dos cânceres de mama se inicia nas células ductais. Alguns tumores começam nos lóbulos e outros, menos frequentes, ocorrem em outros tecidos (Adaptado de ACS, 2014). 
Enquanto o câncer de mama pode ser curado se diagnosticado precocemente, os casos avançados da doença são apenas tratados para aliviar seus sintomas (WHO, 2008).

\subsection{Aspectos do metabolismo energético de células neoplásicas}

Otto Warburg e colaboradores verificaram, em 1927, que as células de câncer apresentam reprogramação do metabolismo energético. Além da respiração mitocondrial, as células realizam, preferencialmente, fermentação da glicose dirigida para a produção de lactato (Figura 2) como via de produção de energia, mesmo na presença de oxigênio (WARBURG et al, 1927). Este fenômeno ficou conhecido como glicólise aeróbia ou efeito Warburg (ZONG et al, 2016).

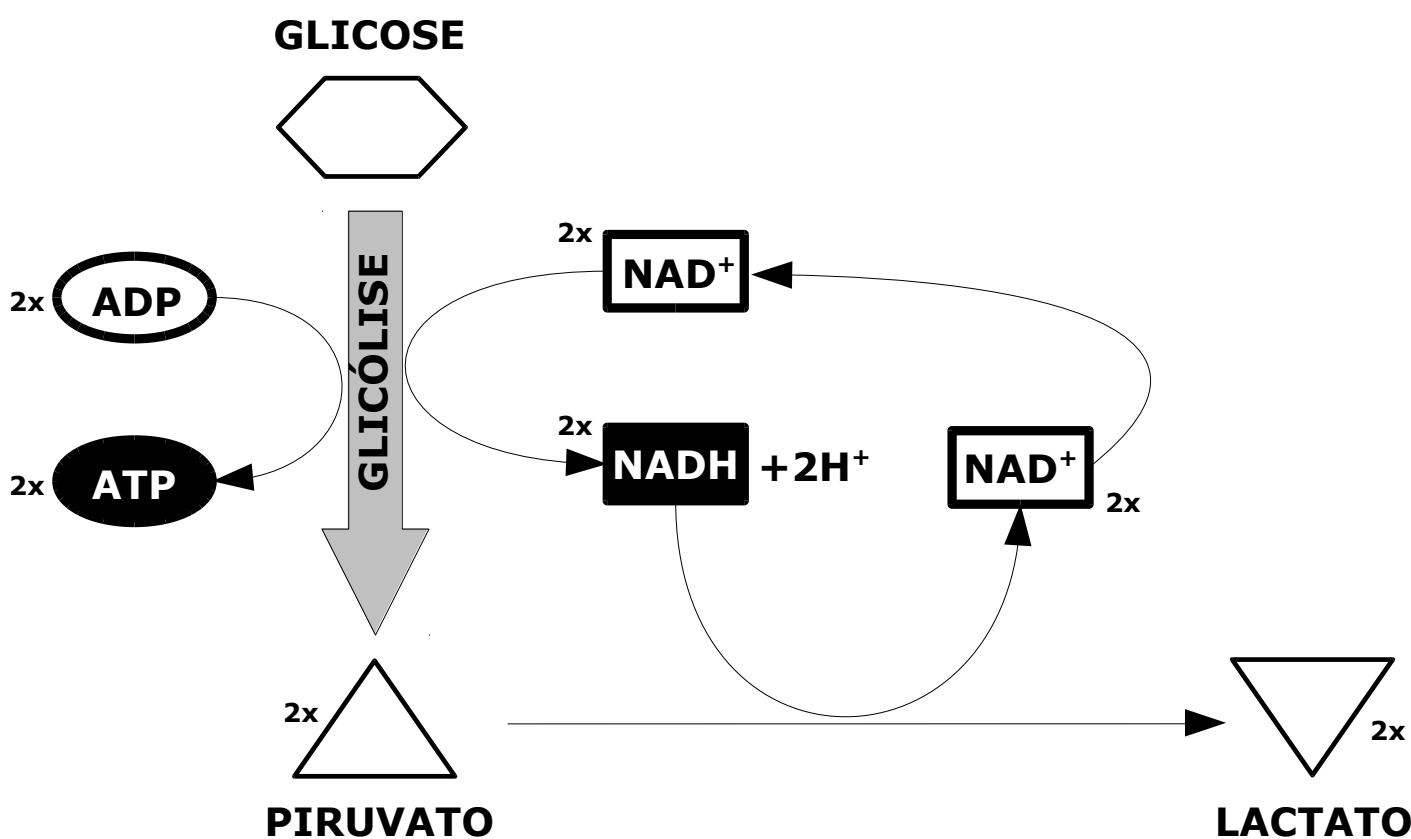

Figura 2. Representação esquemática da fermentação láctica. Em células normais a conversão do piruvato em lactato ocorre em condições anaeróbias, como nos casos de intensa atividade das células musculares. Este processo de fermentação resulta em consumo da molécula NADH produzida na via glicolítica, regenerando $\mathrm{NAD}^{+}$, que é requerida nas etapas da glicólise. Em condições aeróbias o NADH é carreado para a mitocôndria, retornando ao citoplasma somente após sua oxidação pela cadeia transportadora de elétrons (Adaptado de Alberts et al, 2008).

A disfunção mitocondrial foi apontada como a responsável pela glicólise aeróbia (SHARMA et al, 2011; SRINIVASAN et al, 2016). Esta disfunção pode gerar estresse oxidativo devido a deficiência na cadeia transportadora de elétrons. 
Células SKBR3 (adenocarcinoma de mama humano) e 4T1 (carcinoma mamário murino) que apresentam produção elevada de espécies reativas de oxigênio (ERO), ocasionada pela disfunção mitocondrial induzida por inibição do complexo I da cadeia respiratória, exibem maior motilidade e invasibilidade, comportamento que pode ser interrompido por inibição da formação de ERO (MA et al, 2013). Todavia, outras pesquisas mostram que o complexo I funcional é necessário para o fenótipo glicolítico, pois preserva a fosforilação oxidativa e permite a adaptação das células de câncer à hipóxia, sustentando a progressão do tumor (CALABRESE et al, 2013). O complexo I é o primeiro e o maior complexo protéico da cadeia transportadora de elétrons, os quais são recebidos das moléculas NADH e FADH 2 (GRIGORIEFF et al, 2009).

A eficiência na produção de ATP é reduzida no processo de fermentação em comparação com a energia obtida pela fosforilação oxidativa (Figura 3), o que implica em mecanismo compensatório para que as células de câncer obtenham a energia necessária para a sua proliferação (HANAHAN \& WEINBERG, 2011). Foi observado que, para manter 0 aporte energético, as células MCF-7 (adenocarcinoma mamário humano) apresentam como estratégia a superexpressão de GLUT-1, um transportador de glicose basal encontrado em todos os tecidos, como também hiperexpressa GLUT-12, uma proteína regulada por insulina, que também está presente no coração, músculo esquelético, próstata, intestino delgado e tecido adiposo (ROGERS et al, 2002). Também foi observado em células tumorais ou transformadas o aumento da captação de glicose, mesmo sem aumentar o número de transportadores de glicose, da atividade glicolítica e da produção de lactato (ZHENG et al, 2013; JIANG et al, 2015). 


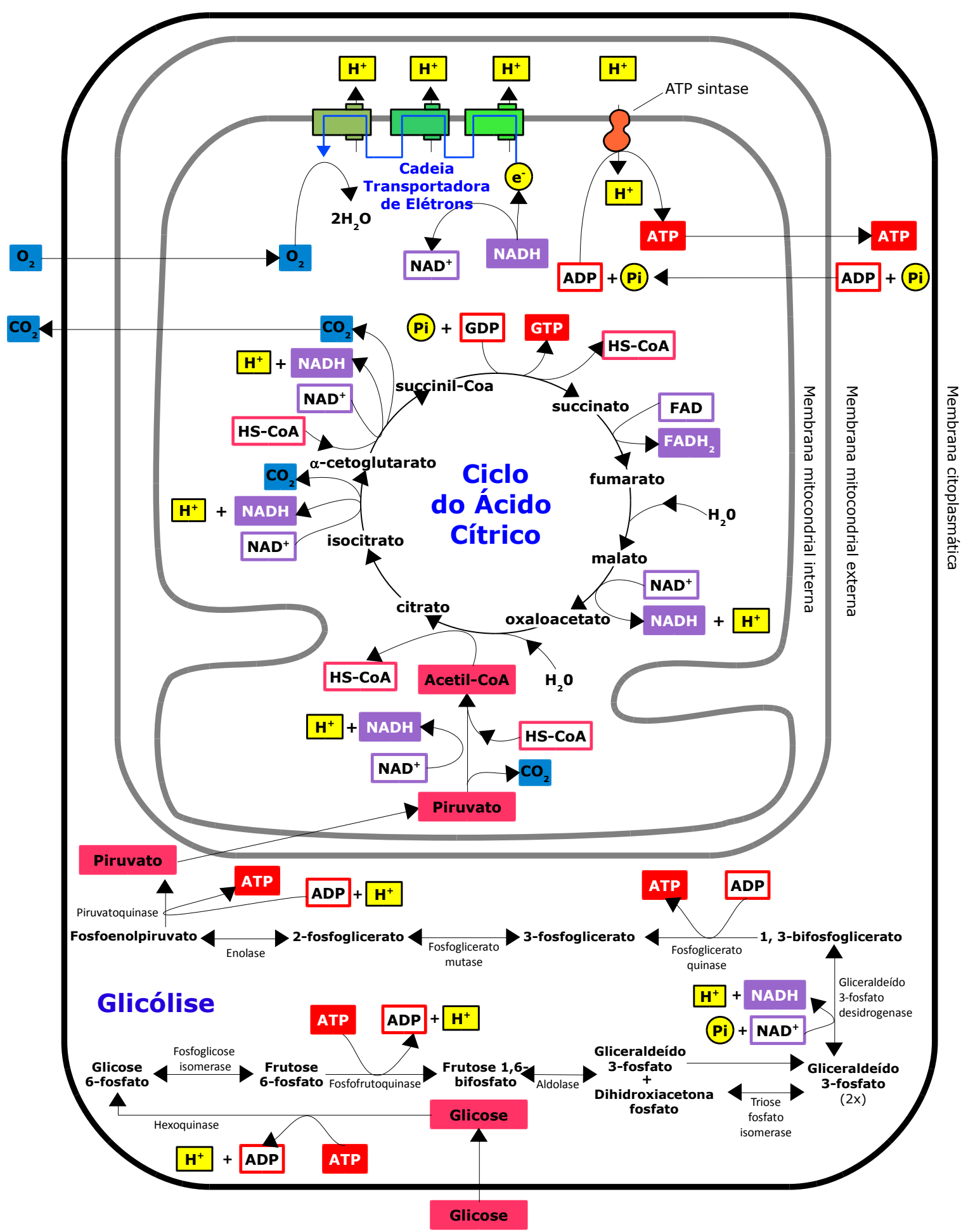

Figura 3. Resumo do metabolismo da glicose. A molécula de glicose é degradada em uma série de reações catalisadas por enzimas. A glicose é fosforilada no citoplasma pela hexoquinase, impedindo sua saída da célula devido à carga negativa. $O$ controle da via glicolítica se dá na regulação da atividade da fosfofrutoquinase. A introdução do segundo grupo fosfato (Pi) pela enzima impede a interrupção da glicólise, que gera 2 ATP, 2 NADH e 2 piruvato. Esta molécula entra na mitocôndria e é convertida em acetil-CoA. Na matriz mitocondrial, a acetil-CoA é descarboxilada no ciclo do ácido cítrico, reduzindo $\mathrm{NAD}^{+}$a $\mathrm{NADH}$ e $\mathrm{FAD}$ a $\mathrm{FADH}$. Os elétrons de alta energia armazenados em NADH e $F A D H_{2}$ são removidos e, então, transferidos para o oxigênio $\left(O_{2}\right)$ via cadeia transportadora de elétrons na membrana interna da mitocôndria. Este transporte produz um gradiente eletroquímico de prótons transmembrana. A força próton-motriz gerada impulsiona a síntese de ATP pela ATP sintase. A oxidação completa da glicose gera um saldo líquido de 30 moléculas de ATP (Adaptado de Alberts et al, 2008). Figura fora de escala. 
A glicólise pode ser regulada por citrato no citoplasma. A molécula inibe a atividade da enzima fosfofrutoquinase - PFK (NEWSHOLME et al, 1977) como também sofre clivagem, formando ácidos graxos e malato. Este é importado para a mitocôndria por sistema antiporte e consumido no ciclo do ácido cítrico (CATALINARODRIGUEZ et al, 2012), conforme esquematizado na Figura 4.

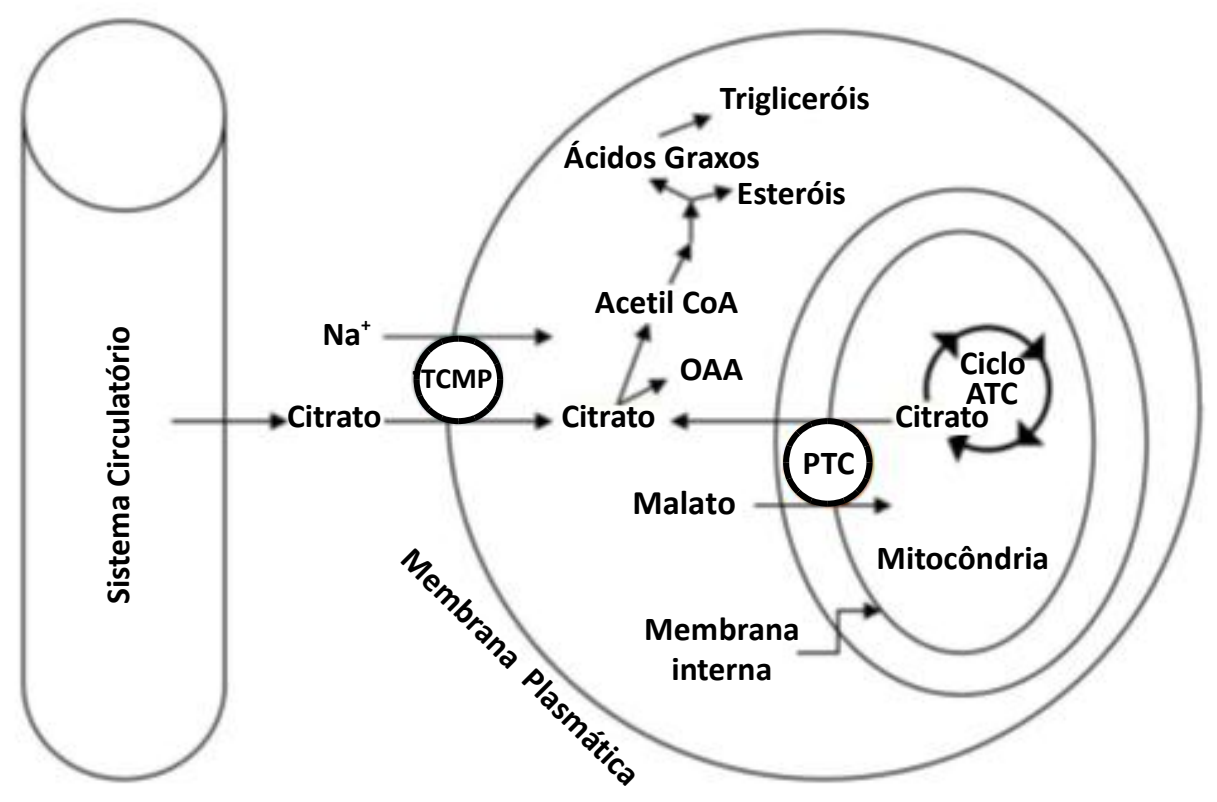

Figura 4. Representação esquemática do transporte de citrato na célula. $O$ citrato extracelular atravessa a membrana plasmática por sistema simporte com o íon sódio, via proteína transportadora (TCMP). A membrana externa da mitocôndria é permeável ao citrato citoplasmático. No entanto, a molécula formada no ciclo do ácido tricarboxílico (ATC) é exportada da matriz mitocondrial por sistema antiporte com o malato através de proteína transportadora (PTC) na membrana interna (Adaptado de Sun et al, 2010). Figura fora de escala.

O citrato é um metabólito intermediário resultante da reação entre acetilCoenzima A, formado a partir do produto da glicólise - o piruvato, e oxaloacetato, molécula presente na mitocôndria (IACOBAZZI \& INFANTINO, 2014). A formação do citrato foi experimentalmente demonstrada por Krebs e colaboradores, que teorizaram que carboidrato é oxidado numa sequência de reações que consome oxaloacetato e o restaura ao final de um ciclo que ficou conhecido como ciclo do ácido cítrico (KREBS et al, 1938; KREBS, 1940), conforme ilustra a figura 3.

Em condições de excesso de energia na célula, o citrato pode ser exportado da mitocôndria para o citoplasma inativando alostericamente PFK. A enzima catalisa a reação irreversível que converte frutose-6-fosfato em frutose 1,6-bifosfato. Uma vez que este substrato seja formado, a via glicolítica não pode mais ser 
interrompida (NEWSHOLME, 1976). Assim, excesso de citrato resulta na inibição da glicólise por retroalimentação negativa (PORPORTATO, 2011).

\subsection{Citrato e câncer}

Pesquisas de biomarcadores metabolômicos têm sido uma ferramenta utilizada para identificar assinaturas metabólicas associadas a doenças como o câncer (CHENG et al, 2015; GÜNTHER, 2015; PALMA et al, 2016) e para desenvolver terapias alvo para o metabolismo do tumor (GALLUZZI et al, 2013; KISHTON \& RATHMELL, 2015) ou mesmo terapia personalizada (JENEY et al, 2016).

Foi verificado que a exportação de citrato da mitocôndria para o citoplasma em células tumorais contribui para a proliferação celular, ao passo em que mantém a homeostase da organela, estabilizando seu potencial de membrana; e que os níveis de expressão do transportador de citrato mitocondrial são elevados em linhagens como MDA-MB-231 (carcinoma mamário humano) e quase indetectáveis em MCF$10 \mathrm{~A}$ (células epiteliais de mama humana) in vitro. Foi observado, ainda, que a tumorigênese foi inibida ao suprimir o transporte de citrato dependente desta proteína em fêmeas balbc/nude com tumor MDA-MB-231 (CATALINA-RODRIGUEZ et al., 2012).

É reconhecido que células de câncer de mama também apresentam fenótipo lipogênico. O citrato produzido no ciclo do acido cítrico é exportado da mitocôndria para o citoplasma e convertido pela enzima ATP citrato liase (ACLy) em acetil-CoA, que é requerida para a síntese dos ácidos graxos. Foi verificado que a inibição de ACLy é mais efetiva na limitação da viabilidade celular e na redução dos níveis de citrato no citoplasma do que a inibição da proteína transportadora de citrato (OZKAYA et al, 2015). A ativação da ACLy, verificada em células MCF-7, é fundamental para acumulação lipídica decorrente da síntese de ácidos graxos de novo no citoplasma.

O transporte de citrato para o citoplasma e conseguinte conversão para a biossíntese lipídica é uma necessidade das células tumorais para fornecer os ácidos graxos requeridos para a proliferação celular. Assim, a glicólise fornece ATP, enquanto a ativação das vias anabólicas garante as macromoléculas para as novas células (VANDER HEIDEN et al, 2009). 
Baixos níveis de citrato e injúria na respiração mitocondrial foram observados em células tumorais resistentes ao quimioterápico paclitaxel. A indução da acumulação de citrato aumentou a suscetibilidade das células ao tratamento por inibição da glicólise e inativação da glicoproteína-P, que está relacionada com a resistência a multidrogas (ZHOU et al, 2015). Ainda, verificou-se que a resistência das células de câncer de mama, positivo para ErbB2, a ação do agente terapêutico Trastuzumab (Herceptin ${ }^{\circledR}$; Genetech Inc.), um anticorpo monoclonal dirigido a ErbB2, decorre do aumento da glicólise via HSF1 (Heat Shock Factor 1) e LDH-A (Lactato Deidrogenase A), que converte piruvato a lactato. A eficiência do tratamento para afetar o crescimento do tumor acontece quando Trastuzumab inibe a glicólise via desregulação da expressão de HSF1 e LDH-A (ZHAO et al, 2011).

O uso do citrato como terapia antitumoral tem sido avaliado em linhagens celulares de diferentes tipos de cânceres, tais como: mesotelioma pleural (ZHANG et al, 2009), câncer gástrico (LU et al, 2011), neuroblastoma (KRUSPIG, 2012) e câncer ovariano (LINCET et al, 2013). Foi verificado que o citrato, de maneira dependente da concentração, induziu eventos relacionados com a apoptose, tais como: inibição da expressão de Mcl-1, um membro das proteínas anti-apoptóticas da família BCL-2; ativação de caspases; clivagem da poli (ADP-ribose) polimerase PARP; e liberação do citocromo c. A mitocôndria responde a estímulos fisiológicos ou patológicos participando do mecanismo de morte celular controlado (KERR et al, 1972). O processo de apoptose pode ser desencadeado pela liberação do citocromo C no citosol (LIU et al, 1996), cuja inibição é regulada via proteínas como a Bcl-2 (KLUCK et al, 1997), ou indução é regulada pela atividade de p53 via proteínas como a Bax (SCHULER et al, 2000). O efluxo de citocromo c da mitocôndria resulta na sua ligação com Apaf-1 (ZOU, 1997; SCHULER et al, 2000) e ativação de uma cascata de caspases (LIU et al, 1996; KLUCK et al, 1997; ZOU, 1997; SCHULER et al, 2000), que transloca o fosfolipídio fosfatidilserina da monocamada interna da membrana plasmática para a externa, sinalizando aos macrófagos para promover a fagocitose (FADOK et al, 1992).

Também foram reportados dois casos de pacientes com câncer - carcinoma medular de tireóide e mesotelioma peritoneal - que apresentaram melhora do quadro clínico quando receberam cápsulas de citrato por via oral como tratamento antineoplásico (BUCAY, 2009; 2011). 
Visando potencializar a citotoxicidade em células de câncer, tem sido avaliado o efeito sinérgico do citrato combinado com outros agentes antitumorais. $A$ combinação com resveratrol, um composto fosfofenólico encontrado em açúcares, inibe a atividade da enzima PFK, afetando o consumo de glicose e produção de lactato (GOMEZ et al, 2013). Associado a cisplatina, foi constatado inibição de PFK, depleção de ATP e redução nos níveis de expressão de proteínas anti-apoptóticas (ZHANG et al, 2009).

Considerando as diferenças no metabolismo energético de células normais e tumorais, neste estudo foram investigados os efeitos produzidos pelo citrato no metabolismo de fibroblastos e de células da linhagem de adenocarcinoma mamário humano. 


\section{JUSTIFICATIVA}

O câncer de mama é a neoplasia mais incidente em mulheres, excluindo o de pele não melanoma. Estima-se que em 2016 surjam 57.960 novos casos no Brasil, representando $28,1 \%$ dos cânceres incidentes (INCA, 2016). O câncer é uma doença genética cuja origem depende do acúmulo de múltiplos eventos mutacionais (HANAHAN \& WEINBERG, 2011), o que dificulta o desenvolvimento de um tratamento capaz de afetar todos os mecanismos de sinalização envolvidos para o surgimento ou para a sobrevivência de células neoplásicas. Essa característica demanda a pesquisa de novos agentes farmacológicos que sejam mais eficazes no potencial antitumoral e na seletividade citotóxica ao atuarem em processos-chave do funcionamento das células de câncer.

O citrato é uma molécula que desempenha função alostérica na regulação da glicólise, principal via para obtenção de energia pelas células de câncer. Investigar os efeitos produzidos pelo agente no metabolismo de células com fenótipo glicolítico fornece importantes contribuições para o desenvolvimento de formulações com aplicação na terapia do câncer de mama. 


\section{OBJETIVOS}

\subsection{Objetivos gerais}

Investigar alterações estruturais e metabólicas em células tumorais (MCF-7) e não-tumorais (fibroblastos) induzidas por citrato, in vitro.

\subsection{Objetivos específicos}

- Mensurar a captação de citrato;

- Avaliar a ação do citrato no que se refere a:

- Alterações morfológicas e ultraestruturais;

- Citotoxicidade, investigando ação da enzima desidrogenase mitocondrial;

- Inibição da glicólise via enzima fosfofrutoquinase - PFK, mensurando atividade de PFK e produção de lactato;

- Estresse oxidativo, quantificando formação de espécies reativas de oxigênio e potencial de membrana mitocondrial. 


\section{MATERIAL E MÉTODOS}

\subsection{Materiais, reagentes e equipamentos}

\section{Produto (código)}

2,7-diacetato de diclorofluoresceína (D6883)

Acetato de uranila (06)

Acetona PA (1239-1)

Antibiótico-antimicótico (15240)

Bicarbonato de sódio PA (306)

Brometo de 3-[4,5-dimetil-tiazol-2-il]-2,5difeniltetrazólio (M6494)

Câmara de Neubauer não espelhada (ATC-110010)

Centrífuga $5424 \mathrm{R}$

Citômetro de fluxo FACScan

Citrate Assay Kit (MAK057)

Citrato de sódio tribásico dihidratado (714020)

Cloreto de cálcio diidratado (2382)

D (+) Sacarose PA (228)

Dihidrocloridrato de 4',6-diamidino-2fenilindol (D1306)

Dimetylsulfóxido (34869)

Espectrofotômetro SpectraMax $\left.{ }^{(}\right)$M5

Etanol PA (1336-5)

Filtro de rotação com massa molecular de corte de 10kDa (UFC5010)

Formaldeído PA (1643)

Frasco para cultura de células aderentes (831810002)

Freezer MDF-U53VC

Glutaraldeído PA (16220)

\section{Fabricante (Origem)}

Sigma-Aldrich $\left.^{(}\right)$EUA)

Fisher Scientific Company (EUA)

Dinâmica (Brasil)

Gibco $^{(}$-Life Technologies ${ }^{\text {TM }}$ (EUA)

Vetec (Brasil)

Molecular Probes ${ }^{\circledR}$-Life

Technologies $^{\mathrm{TM}}$ (EUA)

Optik Labor (Alemanha)

Eppendorf (Alemanha)

Becton Dickinson (EUA)

Sigma-Aldrich $^{(}$(EUA)

Sigma-Aldrich $^{\circledR}$ (EUA)

Merck (Alemanha)

Vetec (Brasil)

Molecular Probes ${ }^{\circledR}$-Life

Technologies $^{\text {TM }}$ (EUA)

Sigma-Aldrich $\left.^{(}\right)$EUA)

Molecular Devices (EUA)

Dinâmica (Brasil)

Merck Millipore (Alemanha)

Dinâmica (Brasil)

Sarstedt (Brasil)

Sanyo (Japão)

Electron Microscopy Sciences (EUA) 
Incubadora com atmosfera úmida (310)

\section{Lactate Assay Kit (MAK064)}

Lâmina de vidro 25 x 75 mm (217105-1)

Lamínula circular 13mm (G13C)

Linhagem celular MCF-7(0162)

Meio de cultura Dulbecco's Modified

Eagle's Medium (D5648)

Microscópio confocal de varredura a laser SP5

Microscópio de contraste de fase

invertido AxioVert 100

Microscópio Eletrônico de Transmissão JEM 1011

Paclitaxel (T7402)

Paraformaldeído PA (19208)

Peróxido de Hidrogênio PA (1857)

PFK Activity Colorimetric Assay Kit (MAK093)

Placas para cultura de poliestireno (K12)

Resina Spurr (14300)

Rodamina 123 (R8004)

Solução anti-desbotamento (P36930)

Solução de azul de tripan a 0,4\% (15250061)

Soro fetal bovino (12657)

Tampão cacodilato de sódio triidratado (12310)

Tampão fosfato salina (590338)

Tetróxido de ósmio (20816-12-0)

Tripsina a 0,25\%/EDTA (T4049)

Triton X-100 (T8787)

Ultramicrótomo EM UC7
Thermo Scientific ${ }^{\mathrm{TM}}$

Sigma-Aldrich $\left.{ }^{(}\right)$(EUA)

Bioslide (China)

Vidrobras (Brasil)

Banco de Células do Rio de Janeiro (Brasil)

Sigma-Aldrich ${ }^{\circledR}$ (EUA)

Leica (Alemanha)

Zeiss $\left.^{(}\right)$(Alemanha)

Jeol $^{(\circledast)}$ (Japão)

Sigma-Aldrich $^{\circledR}($ EUA)

Electron Microscopy Sciences (EUA)

Dinâmica (Brasil)

Sigma-Aldrich $^{(}$(EUA)

Kasvi (Brasil)

Electron Microscopy Sciences (EUA)

Sigma-Aldrich $\left.{ }^{(}\right)$EUA)

Molecular Probes ${ }^{(}-$Life

Technologies $^{\mathrm{TM}}$ (EUA)

Gibco $^{\circledR}$-Life Technologies ${ }^{\text {TM }}$ (EUA)

Gibco $^{(\circledast)}$-Invitrogen ${ }^{\mathrm{TM}}$ (EUA)

Electron Microscopy Sciences (EUA)

Laborclin (Brasil)

Electron Microscopy Sciences (EUA)

Sigma-Aldrich $^{(}$(EUA)

Sigma-Aldrich $^{(}$(EUA)

Leica (Alemanha) 


\subsection{Cultura e manutenção das células}

Células MCF-7 foram obtidas do Banco de Células do Rio de Janeiro. Tratase de uma linhagem de células epiteliais extraídas de uma efusão pleural de tumor metastático de mama humana (SOULE et al, 1973). Cultura primária de fibroblastos normais derivaodos de polpa dentária humana foi cedida pelo Departamento de Genética e Morfologia da Universidade de Brasília. Este tipo celular foi selecionado por constituir o estroma de tecidos tumorais e por interagir ativamente com as células de câncer no microambiente do tumor (MAGDALENA et al, 2010). Ainda, a opção pela cultura primária foi determinada para evitar as possíveis alterações no metabolismo energético de células imortalizadas para cultivo in vitro.

Fibroblastos e células MCF-7 foram semeadas em frascos de cultura celular com meio Eagle modificado por Dulbecco (Dulbecco's Modified Eagle's Medium DMEM), suplementado com 3,7g/L de bicarbonato de sódio, soro fetal bovino (SFB) a $10 \%$ e antibiótico-antimicótico (100 unidades $/ \mathrm{mL}$ de penicilina e $100 \mathrm{mg} / \mathrm{mL}$ de estreptomicina) a $1 \%$.

As células foram mantidas em incubadora com atmosfera úmida a $37^{\circ} \mathrm{C}$ e $5 \%$ de $\mathrm{CO}_{2}$ e o meio de cultura foi renovado a cada três dias. Para subcultivo e plaqueamento, as células foram desaderidas do frasco com solução de Tripsina a 0,25\%/EDTA e o número de células viáveis foi estimado por quantificação direta em câmara de Neubauer pelo método de exclusão do corante azul de tripan a 0,4\%, utilizando a fórmula:

$$
(Q 1+Q 2+Q 3+Q 4) / 4 \times \text { fator de diluição } \times 10^{4}=n^{\circ} \text { de células } / m L
$$

sendo Q1, Q2, Q3 e Q4 os quatro quadrantes da câmara de Neubauer.

\subsection{Teste de viabilidade celular}

O método colorimétrico MTT foi selecionado para mensurar a viabilidade de células tumorais e não-tumorais após tratamento com citrato. O método avalia, por espectrofotometria, a ação da enzima mitocondrial tetrazólio-succinatodesidrogenase de células alvo intactas, que metabolizam o substrato MTT (brometo 
de 3-[4,5-dimetil-tiazol-2-il]-2,5-difeniltetrazólio) e produzem cristais de formazan (BERG, 1990).

A escolha das concentrações de citrato foi baseada nos testes realizados por Lu e colaboradores (2011), que utilizaram as doses seriadas de 5, 10 e $20 \mathrm{mM}$. No entanto, neste trabalho foram utilizadas doses seqüenciais para observar a faixa de concentração que produz efeito estimulatório, de insensibilização ou de inibição do crescimento.

Para o ensaio, foram cultivadas $5 \times 10^{3}$ células/poço em placas de cultura com 96 poços. Após adesão, as amostras foram tratadas em triplicata com solução aquosa de citrato ( $\mathrm{pH} 7,3$ ), nas concentrações de 5, 10, 15, 20, 25 e $30 \mathrm{mM}$, e incubadas em atmosfera úmida a $37^{\circ} \mathrm{C}$ e $5 \%$ de $\mathrm{CO}_{2}$ por 24 e 48 h. O grupo controle negativo não recebeu tratamento e Dimetilsulfóxido (DMSO) foi utilizado como controle branco.

Após cada tempo experimental, o tratamento foi substituído por $150 \mu \mathrm{L} /$ poço de solução com $0,5 \mathrm{mg} / \mathrm{mL}$ de MTT em meio de cultura. As células foram novamente incubadas por duas horas e quarenta e cinco minutos protegidas da luz. Depois deste intervalo a solução foi removida e, por fim, foram adicionados $200 \mu \mathrm{L} /$ poço de DMSO para solubilização dos cristais roxos de formazan. Imediatamente, foi realizada a leitura da absorbância a $595 \mathrm{~nm}$ de comprimento de onda em espectrofotômetro com auxílio do software AxionVision 4.7.1.

Os resultados dos testes de citotoxicidade foram analisados com o apoio do software estatístico GraphPad Prism ${ }^{\circledR}$ 6.01. As porcentagens de viabilidade celular foram normalizadas em função do grupo controle. Para a comparação entre as médias dos grupos tratados com a do grupo controle foi realizada a análise de variância simples (ANOVA one way). Teste $t$ foi utilizado para avaliar a confiança estatística nas porcentagens da viabilidade celular, em relação ao grupo controle, em dados tempo e concentração de tratamento; entre os tempos de 24 e 48 h para o mesmo tipo celular e grupo de tratamento; e entre os tipos celulares em dados tempo e concentração de tratamento. A concentração inibitória de $50 \%\left(\mathrm{Cl}_{50 \%}\right)$ das células para cada tempo experimental foi determinada a partir de um modelo de regressão não-linear baseado na média \pm erro padrão da porcentagem da viabilidade celular referente a três experimentos independentes e com $R^{2}>0,95$. 
O tempo experimental e a concentração inibitória de 50\% das células MCF-7 triados foram utilizados nos demais testes realizados neste trabalho.

\subsection{Alterações morfológicas e ultraestruturais}

Foram utilizados os parâmetros morfométricos área média e razão de aspecto para análise de eventuais alterações da dinâmica mitocondrial, que envolve processos contínuos de fusão e fissão (PICARD et al, 2013), decorrentes de possíveis alterações metabólicas induzidas pelo tratamento com citrato.
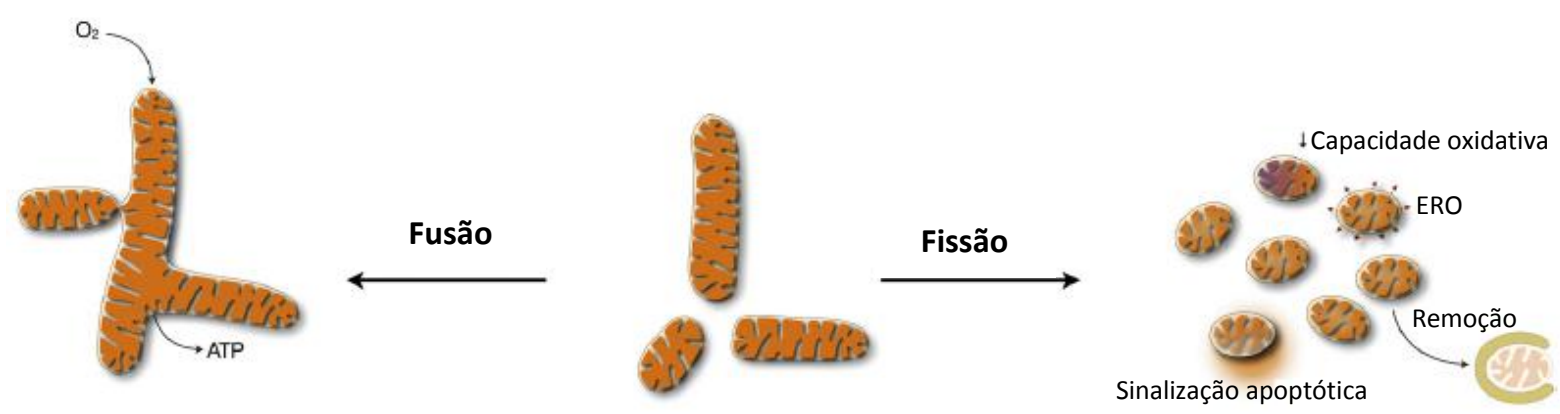

Figura 5. Dinâmica mitocondrial (Adaptado de PICARD et al, 2013).

\subsubsection{Análise por microscopia eletrônica de transmissão}

Foram semeadas $1 \times 10^{6}$ células/poço em placas de cultura com seis poços e incubadas com citrato na concentração de $20 \mathrm{mM}$. Células não tratadas foram utilizadas como grupo controle negativo. Após 24 h de exposição ao tratamento, as alterações morfológicas das células foram visualizadas com microscópio de contraste de fase invertido e fotografadas com auxílio do software AxioVision40V.4.7.1.0.

Em seguida, as células foram desaderidas da placa, lavadas com tampão fosfato salina (PBS) e mantidas em solução fixadora de Karnovisky (glutaraldeído a $2 \%$, paraformaldeído a $2 \%$, sacarose a $3 \%$, cloreto de cálcio $0,005 \mathrm{M}$ e tampão cacodilato de sódio 0,1 M, pH 7,2) em temperatura ambiente por duas horas. Então, as amostras foram lavadas com tampão cacodilato de sódio 0,1M e mantidas em segundo banho a $4 \stackrel{\circ}{ } \mathrm{C}$.

Posteriormente, as células foram pós-fixadas em solução com ferrocianeto de potássio a $0,8 \%$ e tetróxido de ósmio a $1 \%$ por uma hora e, então, lavadas duas 
vezes com água destilada. A contrastação in bloc das amostras foi realizada com solução aquosa de acetato de uranila a $0,5 \%$.

$\mathrm{Na}$ sequência, as células foram lavadas duas vezes com água destilada; desidratadas com acetona em gradientes crescentes de concentração (50, 70, 90 e (2x) 100\%) por 10 minutos cada banho; e infiltradas com solução de acetona PA e resina Spurr, nas proporções 3:1, 2:1, 1:1, 1:2 e 1:3 (v/v) respectivamente, e somente em resina por cinco horas cada etapa. Por fim, as amostras foram emblocadas com resina em estufa de secagem a $63^{\circ} \mathrm{C}$ por $48 \mathrm{~h}$.

Para análise morfométrica das mitocôndrias, foram obtidas secções de 40$50 \mathrm{~nm}$ de espessura do material emblocado em ultramicrótomo e observadas em microscópio eletrônico de transmissão (MET), com apoio do software Gatan Digital Micrograph $^{\mathrm{TM}}$ 1.84.1282.

\subsubsection{Morfometria de mitocôndrias}

Micrografias eletrônicas das células MCF-7 e de fibroblastos foram submetidas a um pré-processamento para remoção de ruído e correção de iluminação heterogênea. Então, foi realizada a segmentação das mitocôndrias (Figura 6) em cada célula selecionada aleatoriamente por meio de procedimentos envolvendo limiarização associada à seleção de pixels contíguos.

Uma vez isoladas, realizou-se, então, a mensuração da área ocupada por cada mitocôndria para cálculo da área média $\left(\mu \mathrm{m}^{2}\right)$. Para definição da razão de aspecto, foi determinado o quociente entre os eixos maior e menor da elipse de melhor ajuste. Os procedimentos para segmentação e para a morfometria das mitocôndrias foram realizados com o auxílio do software Image Pro-Plus 6.0.

Os dados da análise morfométrica foram submetidos ao teste de Grubbs para a detecção de valores discrepantes (outliers). Em seguida, os testes de Kolmogorov-Smirnov e de Bartlett foram utilizados para verificação da distribuição normal e da homogeneidade de variâncias, respectivamente, para realização subsequente de análise de variância (ANOVA one-way) e do teste $t$ para comparação das médias. Os dados foram representados como médias \pm erro padrão das médias (SEM), e as diferenças foram consideradas estatisticamente significativas quando a probabilidade de erro foi menor que $5 \%$. 


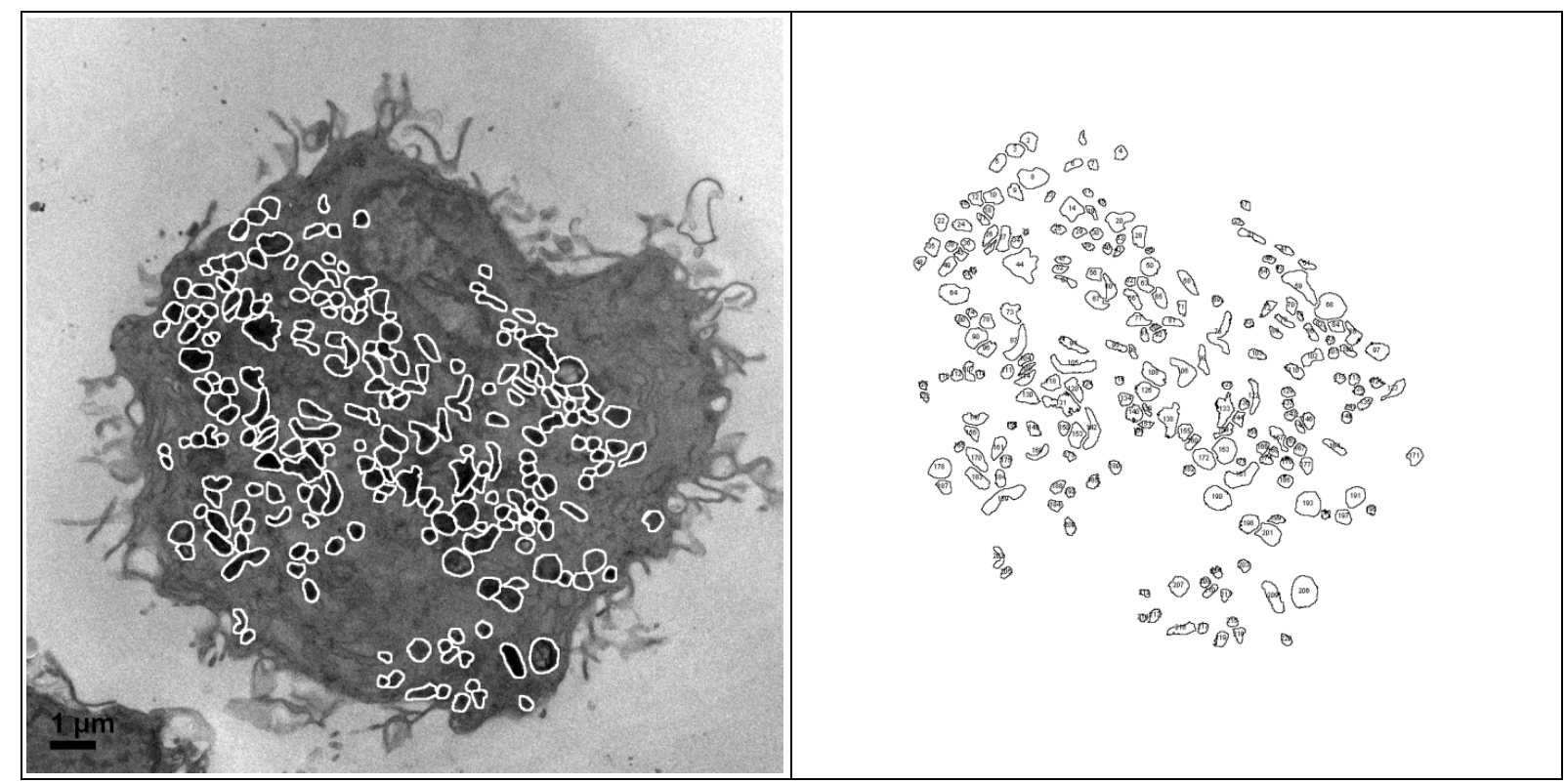

Figura 6. Segmentação das mitocôndrias. Análises morfométricas foram realizadas a partir do isolamento das mitocôndrias de células selecionadas aleatoriamente em micrografias eletrônicas de transmissão.

\subsection{Conteúdo de citrato}

A quantificação e localização do citrato presente nas amostras de fibroblastos e MCF-7 foram determinadas utilizando o reagente Citrate Assay Kit. No ensaio, o citrato é convertido, via oxaloacetato, a piruvato. Esta molécula, então, converte uma sonda incolor em um produto colorimétrico/fluorimétrico.

\subsubsection{Quantificação}

Células semeadas em frascos de cultura $\left(75 \mathrm{~cm}^{2}\right)$ foram tratadas com citrato 20 mM. O grupo controle não recebeu tratamento.

Após $24 \mathrm{~h}$ de incubação, as células foram lavadas com PBS, desaderidas, lavadas novamente e contadas. Não foi utilizado meio de cultura suplementado nestas etapas para evitar interferência das proteínas do soro fetal bovino no ensaio a seguir.

Alíquotas com $1 \times 10^{6}$ células de cada grupo de tratamento foram homogeneizadas em $100 \mu \mathrm{L}$ do tampão fornecido com o kit e centrifugadas a 15.000 x g durante 10 minutos. A fração solúvel foi coletada e o material insolúvel foi descartado. As amostras foram armazenadas em freezer a $-80^{\circ} \mathrm{C}$. 
Para realização do ensaio enzimático, as amostras foram descongeladas e centrifugadas a 14.000 x g por 10 minutos em filtro de rotação com massa molecular de corte de $10 \mathrm{kDa} .20 \mu \mathrm{L} /$ poço da fração desproteinizada foi transferida para placa de 96 poços em triplicata. Foi adicionado tampão até alcançar o volume de 50 $\mu \mathrm{L} /$ poço. Uma amostra de cada triplicata foi definida como controle branco para deduzir o background gerado pelo oxaloacetato ou piruvato presente na fração. A curva padrão do citrato foi construída a partir das absorbâncias da solução padrão, adicionada à placa em duplicata, nas concentrações de 0 (branco), 2, 4, 6, 8 e 10 $\mathrm{nmol} / \mathrm{poço.}$

Em seguida, 50 $\mu \mathrm{L} /$ poço do mix de reação, contendo enzimas e a sonda de marcação, foi adicionado aos padrões, às amostras e aos controles brancos, sendo que neste último as enzimas foram omitidas do mix. As amostras foram incubadas por 30 minutos sob agitação contínua, em temperatura ambiente e no escuro.

A leitura da absorbância foi realizada em espectrofotômetro $(\lambda=570 \mathrm{~nm})$ com apoio do software AxionVision 4.7.1.

\subsubsection{Localização}

Foram cultivadas $5 \times 10^{4}$ células/poço em lamínulas depositadas em fundo chato de placa de 24 poços. Então, uma amostra de cada tipo celular foi tratada com citrato $20 \mathrm{mM}$ por $24 \mathrm{~h}$. Após o tempo de incubação, células tratadas e sem tratamento foram lavadas três vezes com PBS e fixadas com formaldeído a 3,7\% por 30 minutos.

Depois, as células foram lavadas novamente com tampão (3x) e permeabilizadas com solução de Triton X-100 a 0,1\% por 20 minutos. Transcorrido o período, as amostras foram incubadas por 30 minutos com $150 \mu \mathrm{L} /$ poço do mix de reação do reagente Citrate Assay Kit sob agitação contínua, protegidas da luz e em temperatura ambiente. Células não incubadas com o mix de reação também foram utilizadas para averiguar existência de autofluorescência.

$\mathrm{Na}$ sequência, as amostras foram lavadas três vezes com PBS, incubadas com DAPI (dihidrocloridrato de 4',6-diamidino-2-fenilindol) por 5 minutos para marcação do DNA celular e lavadas com tampão novamente. Para finalizar, a montagem das amostras foi realizada em lâminas de vidro com solução antidesbotamento e vedadas com esmalte. A análise da fluorescência $\left(\lambda_{\text {excitação }}=535\right.$ 
$\mathrm{nm} ; \lambda_{\text {emissão }}=587 \mathrm{~nm}$ ) foi realizada por microscopia confocal de varredura a laser com apoio do software LAS AF v. 2.3.6 b5381.

\subsection{Inibição da glicólise via enzima fosfofrutoquinase}

\subsubsection{Inibição da atividade da enzima fosfofrutoquinase}

A inibição da atividade da enzima fosfofrutoquinase (PFK) foi determinada por espectrofotometria, utilizando o reagente PFK Activity Colorimetric Assay Kit. Trata-se de um ensaio enzimático baseado na conversão de ADP em AMP e NADH. Este reduz uma sonda incolor em um produto colorimétrico proporcional à atividade de PFK presente na amostra. PFK catalisa a formação de frutose-1,6-difosfato e ADP a partir de frutose-6-fosfato e ATP.

Alíquotas com $1 \times 10^{6}$ células dos grupos experimentais ( 0 e $20 \mathrm{mM}$ ) foram obtidas e armazenadas conforme descrito na seção 4.5.1.

No ensaio, duplicata do controle positivo fornecido com o kit e triplicatas das frações solúveis $(20 \mu \mathrm{L} /$ poço) foram transferidas para placa de 96 poços. Foi adicionado tampão até alcançar o volume de $50 \mu \mathrm{L} /$ poço. Uma amostra de cada triplicata foi definida como controle branco devido ao background dos substratos ADP e NADH presentes na amostra, que podem gerar sinal.

Foram preparadas duplicatas das concentrações 0 (branco), 2, 4, 6, 8 e 10 nmol/poço da solução padrão de NADH para construir a curva padrão.

Em seguida, aos padrões, às amostras e aos controles positivo e branco foram adicionados $50 \mu \mathrm{L}$ do mix de reação, contendo enzimas, ATP e substrato, conforme descrito pelo fabricante. A atividade cinética de PFK foi analisada em espectrofotômetro a $450 \mathrm{~nm}$ de comprimento de onda, com auxílio do software AxionVision 4.7.1. A leitura das absorbâncias foi realizada a cada cinco minutos a 37 ${ }^{\circ} \mathrm{C}$ até encontrar o valor mais alto que o maior valor do padrão.

\subsubsection{Produção de lactato}

A produção de lactato foi quantificada para averiguar a ocorrência de fermentação pelas células tumorais em condições normais de cultivo (grupo controle) e de inibição da via glicolítica de células submetidas a tratamento com 
citrato. O reagente Lactate Assay Kit foi utilizado para o ensaio, que é baseado em reação enzimática e formação de produto colorimétrico.

Alíquotas com $1 \times 10^{6}$ células de cada grupo de tratamento (0 e $20 \mathrm{mM}$ ) de células MCF-7 foram obtidas, armazenadas e desproteinizadas conforme descrito na seção 4.5.1.

Para o ensaio enzimático, as amostras (20 $\mu \mathrm{L} /$ poço) e a solução padrão de lactato, nas concentrações de 0 (branco), 2, 4, 6, 8 e $10 \mathrm{nmol} /$ poço, foram transferidas para placa de 96 poços em duplicatas. Foi adicionado tampão fornecido com o kit até alcançar o volume de $50 \mu \mathrm{L} /$ poço.

Após, $50 \mu \mathrm{L} /$ poço do mix de reação, contendo enzimas e a sonda de marcação, foram adicionados aos padrões e às amostras. A solução foi preparada conforme instruções do fabricante. A incubação ocorreu por 30 minutos sob agitação contínua, em temperatura ambiente e no escuro. A leitura da absorbância foi realizada a $570 \mathrm{~nm}$ de comprimento de onda em espectrofotômetro com apoio do software AxionVision 4.7.1.

\subsection{Estresse oxidativo}

\subsubsection{Formação de espécies reativas de oxigênio intracelulares}

A formação de espécies reativas de oxigênio (ERO) foi avaliada por citometria de fluxo, utilizando o marcador 2,7-diacetato de diclorofluoresceína (DCFH-DA), que é permeável na célula. Intracelularmente o DCFH-DA é esterificado, formando um produto que se torna fluorescente quando é oxidado por ERO (BASS et al, 1983).

Foram plaqueadas $5 \times 10^{5}$ células/poço em placas de 6 poços. Após adesão, amostras foram tratadas com citrato $20 \mathrm{mM}$ por $24 \mathrm{~h}$ e com peróxido de hidrogênio $200 \mu \mathrm{M}$ (controle positivo) por $3 \mathrm{~h}$. Na sequência, as amostras foram incubadas com $10 \mu \mathrm{M}$ de DCFH-DA em meio de cultura. Após 30 minutos de incubação a $37^{\circ} \mathrm{C}$ e no escuro, as amostras foram coletadas, lavadas duas vezes com PBS e analisadas por citometria de fluxo. Foi mensurada a intensidade da fluorescência de 10.000 células por amostra, com apoio do software Windows ${ }^{\mathrm{TM}}$ FlowMax $^{\circledR}$. Os histogramas foram construídos utilizando o software FlowJo ${ }^{\circledR}$ V.10.1r7. 


\subsubsection{Alteração de potencial de membrana mitocondrial}

O potencial de membrana mitocondrial $(\Delta \Psi)$ foi investigado para averiguar alterações na função bioenergética da organela, utilizando o marcador catiônico Rodamina 123, cuja taxa de decaimento da fluorescência é proporcional ao $\Delta \Psi$ (BARACCA, 2003).

No ensaio, foram utilizadas células sem tratamento (controle negativo), tratadas com citrato $20 \mathrm{mM}$ por $24 \mathrm{~h}$ e células tratadas com paclitaxel $100 \mu \mathrm{M}$ (controle positivo) por $6 \mathrm{~h}$. Em seguida, as células aderidas e em suspensão foram lavadas com PBS e incubadas em solução com $5 \mu \mathrm{g} / \mathrm{mL}$ de Rodamina 123 em meio de cultura por 30 minutos e, então, novamente lavadas com tampão.

As células foram analisadas por citometria de fluxo, conforme descrito na seção 4.7.1. 


\section{RESULTADOS}

\subsection{Citotoxicidade do citrato em fibroblastos e MCF-7}

Cultivados em meio com alto teor de glicose, fibroblastos foram mais suscetíveis à redução de viabilidade nas doses iniciais de tratamento (5 e $10 \mathrm{mM})$, enquanto células MCF-7 não sofreram alterações estatisticamente significativas. Nas concentrações de 25 e 30 mM, o citrato foi citotóxico para ambas as células. No entanto, o tratamento com citrato na concentração de $20 \mathrm{mM}$ foi mais citotóxico em células MCF-7 do que em fibroblastos nos dois tempos experimentais (Figura 7).

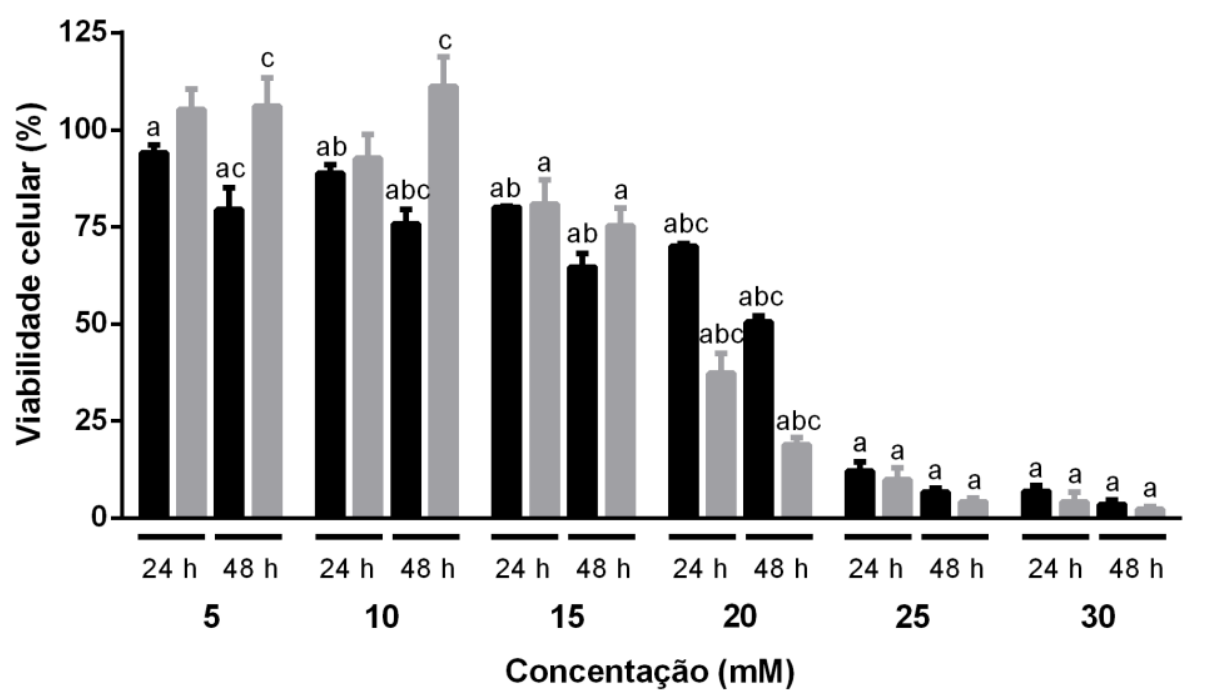

Figura 7. Efeito do citrato na viabilidade celular após tratamento por 24 e $48 \mathrm{~h}$. A viabilidade de fibroblastos e de células da linhagem MCF-7 foi avaliada pelo método colorimétrico MTT. As barras representam a média \pm erro padrão da porcentagem de células viáveis, normalizadas com o grupo controle, referentes a três experimentos independentes e com $R^{2}>0,95$. As letras indicam diferença estatisticamente significativa $(p<0,05)$ na viabilidade (a) das células tratadas em relação ao grupo controle (não mostrado), para dados tempo e concentração de tratamento; (b) do mesmo tipo celular e na mesma concentração de tratamento, nos tempos de 24 e $48 \mathrm{~h}$; e (c) dos diferentes tipos celulares para o mesmo tempo e concentração de tratamento.

A concentração inibitória de cinquenta por cento das células com intervalo de confiança de $95 \%$ foi similar entre fibroblastos e MCF-7 em ambos os tempos de exposição ao tratamento (Tabela 1). 
Tabela 1. Concentração inibitória de $50 \%$ das células com intervalo de confiança de $95 \%$. Fibroblastos e células da linhagem MCF-7 foram cultivados em meio DMEM e tratados com citrato nas concentrações de 0 a $30 \mathrm{mM}$ por 24 e $48 \mathrm{~h}$. A viabilidade celular foi determinada pelo ensaio colorimétrico MTT em três experimentos independentes e com $\mathrm{R}^{2}>0,95$.

\begin{tabular}{ccc}
\hline \multirow{2}{*}{ Tempo (h) } & \multicolumn{2}{c}{ IC $_{\mathbf{5 0}}(\mathrm{mM})$} \\
\cline { 2 - 3 } & Fibroblastos & MCF-7 \\
\hline $\mathbf{2 4}$ & $21,49 \pm 3,91$ & $18,41 \pm 4,01$ \\
\hline $\mathbf{4 8}$ & $21,03 \pm 6,08$ & $16,79 \pm 2,85$ \\
\hline
\end{tabular}

\subsection{Alterações morfológicas e ultraestruturais induzidas por citrato}

A redução na viabilidade celular pôde ser acompanhada pela observação da morfologia dos fibroblastos e das células MCF-7 (Figura 7). A característica de células aderentes verificada nos grupos controle $(0 \mathrm{mM})$ foi sendo substituída pela de células em suspensão nos grupos tratados com citrato por $24 \mathrm{~h}$. O sobrenadante foi coletado e corado com azul de tripan a $0,4 \%$. Foi constatado inviabilidade celular. MCF-7 foi mais suscetível ao tratamento com citrato na concentração de $20 \mathrm{mM}$ do que fibroblastos.
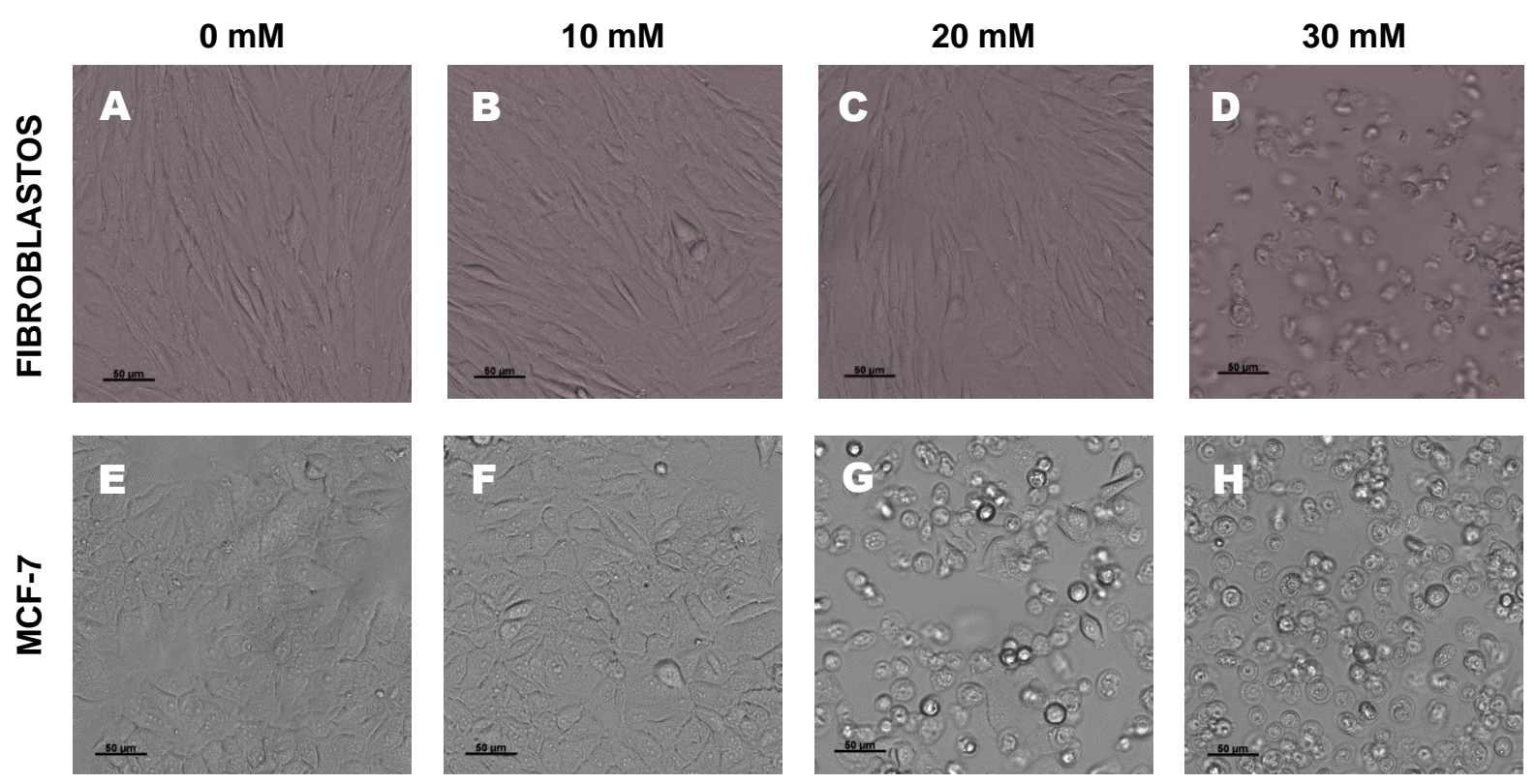

Figura 8. Morfologia celular após tratamento com diferentes doses de citrato. Fibroblastos (A a D) e células MCF-7 (E a H) não tratados (A e E) e tratados com citrato a $10 \mathrm{mM}(\mathrm{B}$ e $\mathrm{F}), 20 \mathrm{mM}(\mathrm{C}$ e $\mathrm{G})$ e $30 \mathrm{mM}(\mathrm{D}$ e H) por $24 \mathrm{~h}$. Células MCF-7 foram mais suscetíveis ao tratamento com citrato do que fibroblastos na concentração de $20 \mathrm{mM}$. Aumento de 320x. 
Análises morfométricas das mitocôndrias a partir de micrografias eletrônicas de células MCF-7 e fibroblastos (Figura 9) apontaram alterações estatisticamente significativas $(p<0,05)$ da área mitocondrial média (Figura 10) das células nãotumorais tratadas com citrato a $20 \mathrm{mM}$ por $24 \mathrm{~h}$ em comparação com o grupo controle.
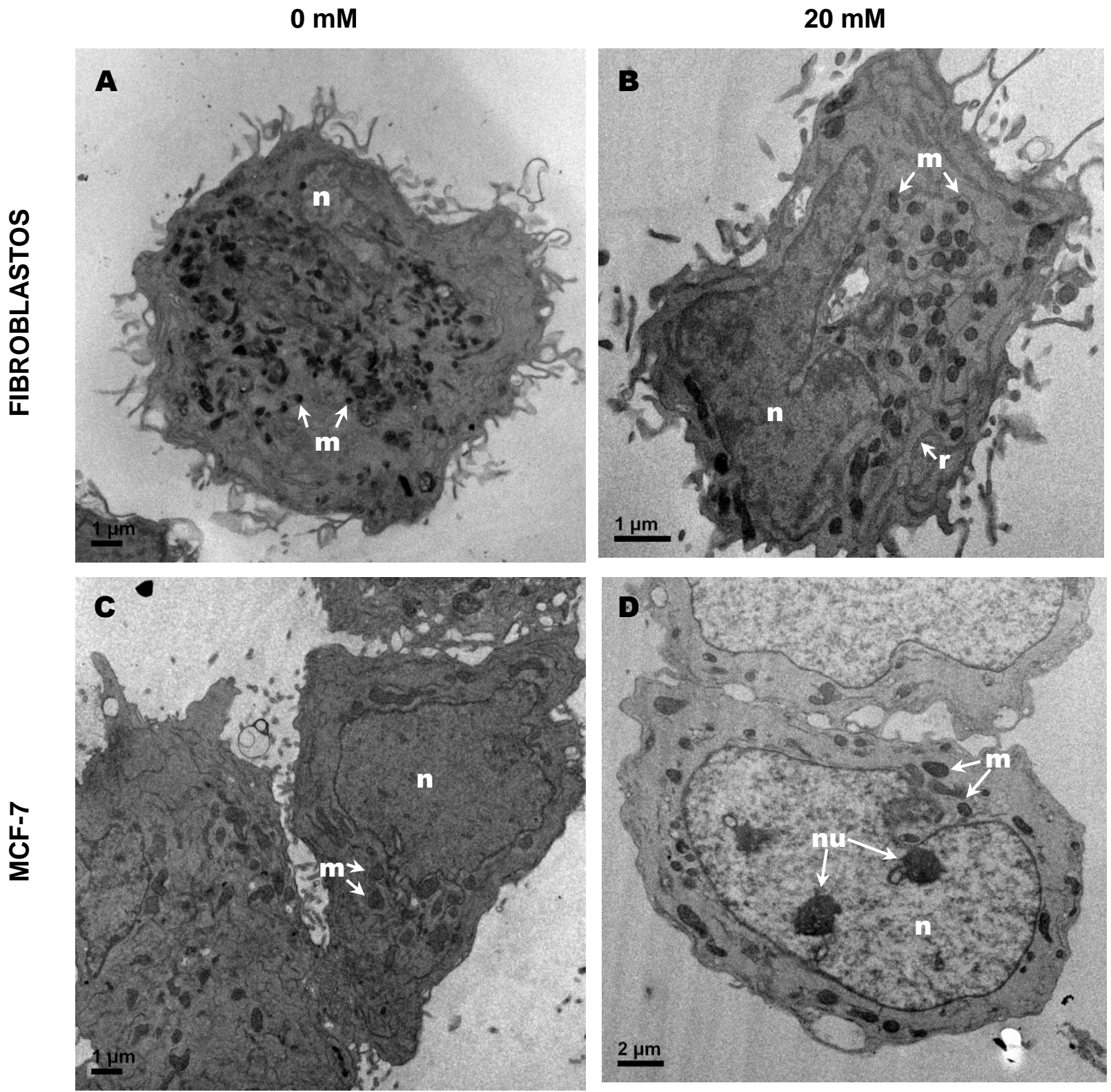

Figura 9. Micrografias eletrônicas de células controle e tratadas com citrato. Fibroblastos (A e B) e células MCF-7 ( $C$ e D) não tratados ( $A$ e C) e tratados com citrato $20 \mathrm{mM}(\mathrm{B}$ e C) por $24 \mathrm{~h}$. Análises morfométricas demonstraram alterações estatisticamente significativas $(p<0,05)$ da área média das mitocôndrias de fibroblastos após tratamento com citrato. Legenda: mitocôndrias $(m)$, núcleo $(n)$; nucléolos (nu) e retículo endoplasmático (r). Aumento de 8k (A e C), 10k (D) e 15k (B). 


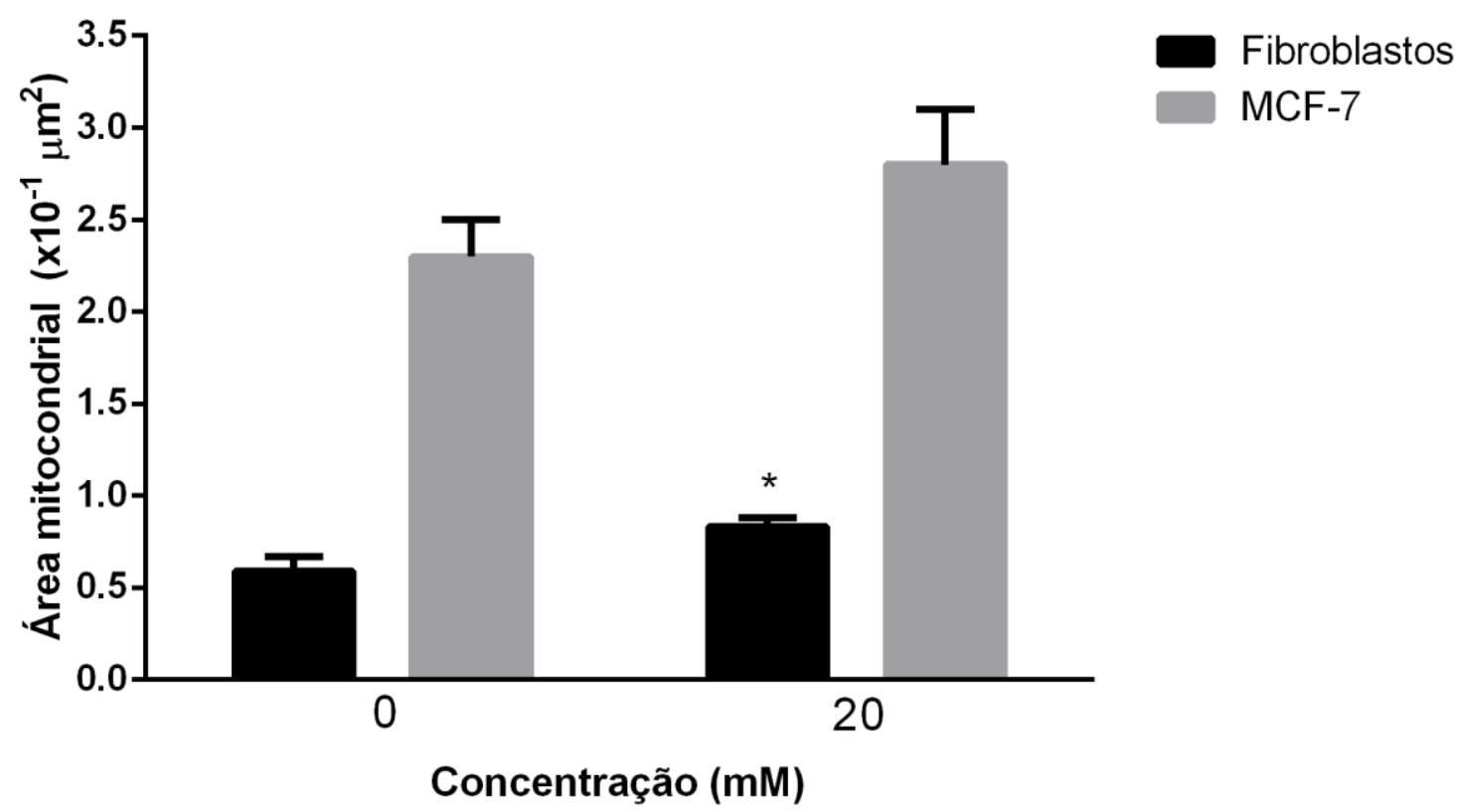

Figura 10. Área mitocondrial média. Fibroblastos e células MCF-7 sem tratamento $(0 \mathrm{mM})$ e tratados com citrato $(20 \mathrm{mM})$ por $24 \mathrm{~h}$ foram avaliados quanto à área mitocondrial média a partir de micrografias eletrônicas. As barras representam a média \pm erro padrão das médias (SEM). * representa diferença estatisticamente significativa entre células tratadas e não tratadas $(p<0,05)$.

No entanto, as células MCF-7 possuem área mitocondrial média maior que a de fibroblastos. A razão de aspecto (Figura 11), porém, manteve-se constante nos dois tipos celulares e diferentes tratamentos.

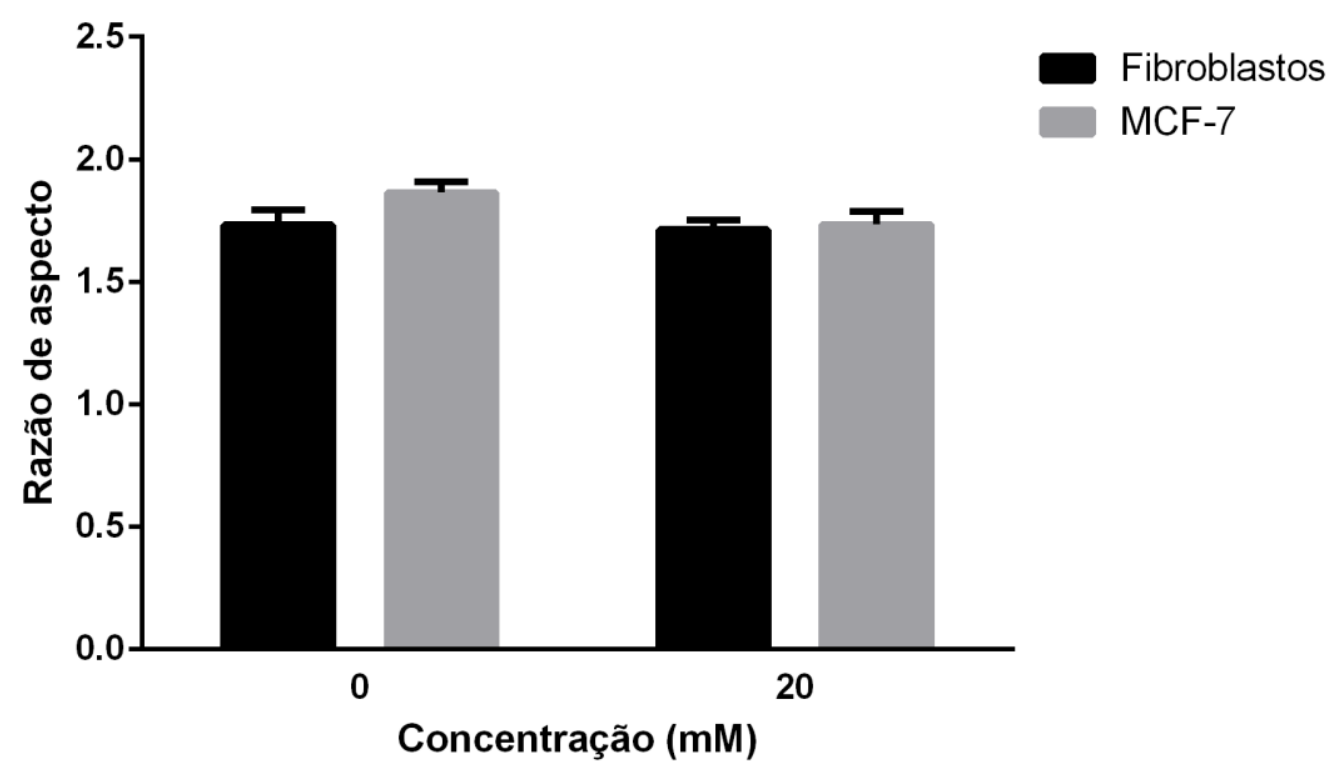

Figura 11. Razão de aspecto das mitocôndrias após tratamento com citrato. Fibroblastos e células MCF-7 não tratados $(0 \mathrm{mM})$ e tratados com citrato $20 \mathrm{mM}$ por $24 \mathrm{~h}$ não apresentaram diferenças estatisticamente significativas $(p>0,05)$ na razão de aspecto das mitocôndrias. As barras mostram a média \pm erro padrão das médias (SEM). 


\subsection{Níveis de citrato}

O ensaio colorimétrico com o reagente Citrate Assay Kit utilizado para mensurar o citrato (Figura 11) demonstrou que células MCF-7 possuem elevado conteúdo intracelular do metabólito relativo ao observado em fibroblastos. Além disso, os níveis da molécula após tratamento com citrato $20 \mathrm{mM}$ por $24 \mathrm{~h}$ não diferiram em ambas as células.

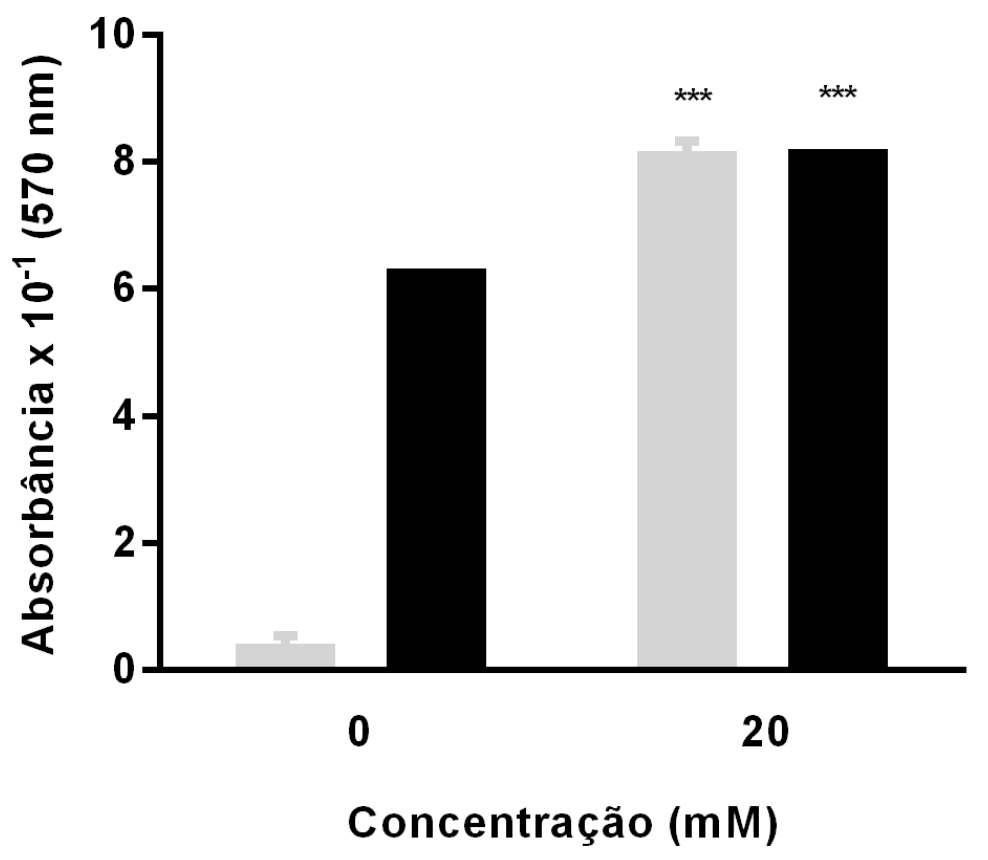

Fibroblastos

MCF-7

Figura 12. Níveis de citrato. Células controle $(0 \mathrm{mM})$ e tratadas com citrato $(20 \mathrm{mM})$ por $24 \mathrm{~h}$ de fibroblastos e MCF-7 foram avaliadas quanto ao conteúdo de citrato utilizando o reagente Citrate Assay Kit. ${ }^{* * *}$ representa diferença estatisticamente significativa entre células tratadas e controle $(\mathrm{p}<$ $0,001)$.

O reagente converte o citrato em piruvato, via oxaloacetato. Assim, os controles brancos (não mostrado) de cada grupo experimental se referem ao conteúdo de piruvato presente na amostra (Figura 13). Células MCF-7 também apresentaram concentração mais elevada desta molécula, em relação aos fibroblastos, nos dois grupos de tratamento (0 e $20 \mathrm{mM})$. 

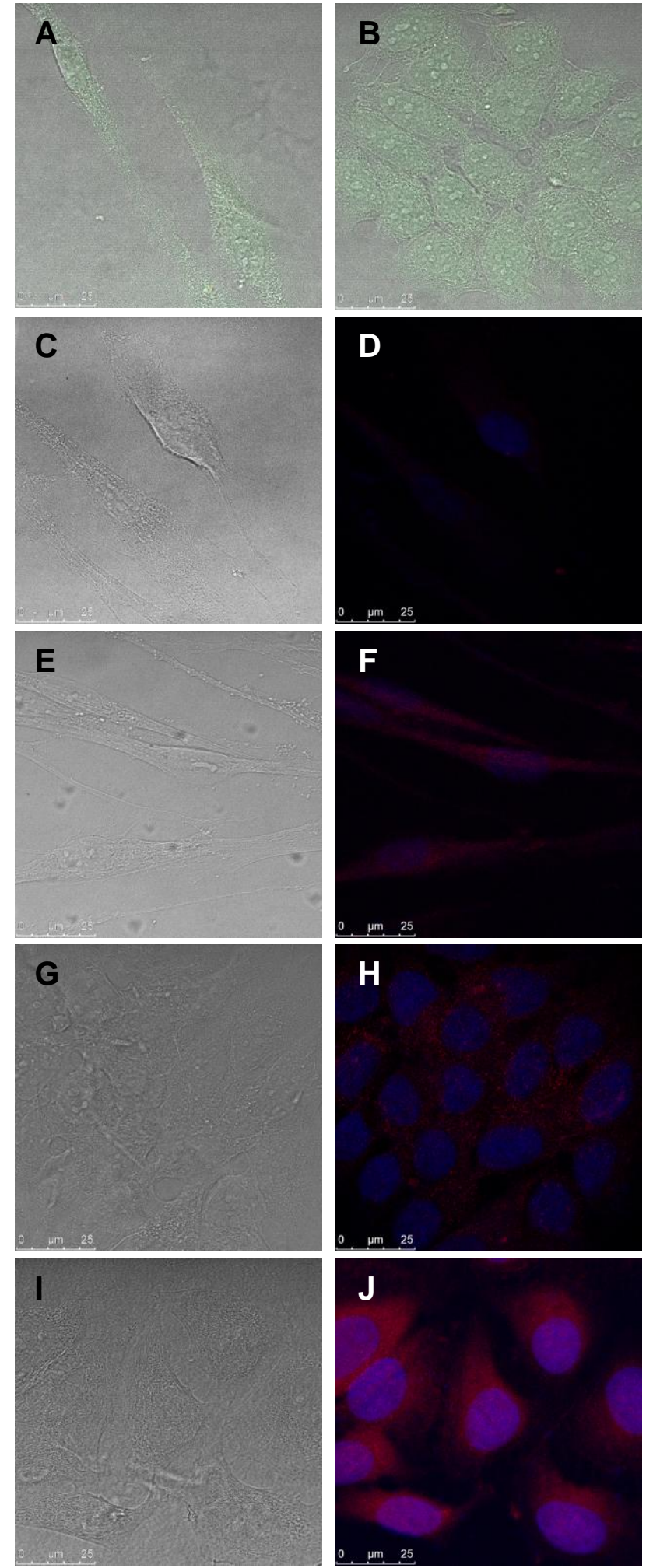

Figura 13. Conteúdo de piruvato. Fibroblastos (A e C-F) e células MCF-7 (B e G-J) sem tratamento $(A, B, C, D, G$ e H) e tratadas $(E, F, I$ e J) com citrato $20 \mathrm{mM}$. As células ( $C$ a J) foram marcadas com DAPI (azul) e com o reagente Citrate Assay Kit (vermelho), que converte citrato a piruvato, via oxaloacetato. A fluorescência vermelha é resultante da conversão de uma sonda incolor pelo piruvato presente na amostra. As imagens C, E, G e I se referem ao campo claro das imagens $D, F, H$ e J, respectivamente. A e B mostram sobreposição de imagens adquiridas nos três canais. Ambas as células apresentaram autofluorescência no canal verde. 


\subsection{Atividade da enzima fosfofrutoquinase}

Tratamento com citrato $20 \mathrm{mM}$ ocasionou redução $(p<0,05)$ da atividade da enzima fosfofrutoquinase (Figura 14) em células MCF-7 após $24 \mathrm{~h}$ de exposição, quando comparado com o grupo controle (0 mM).

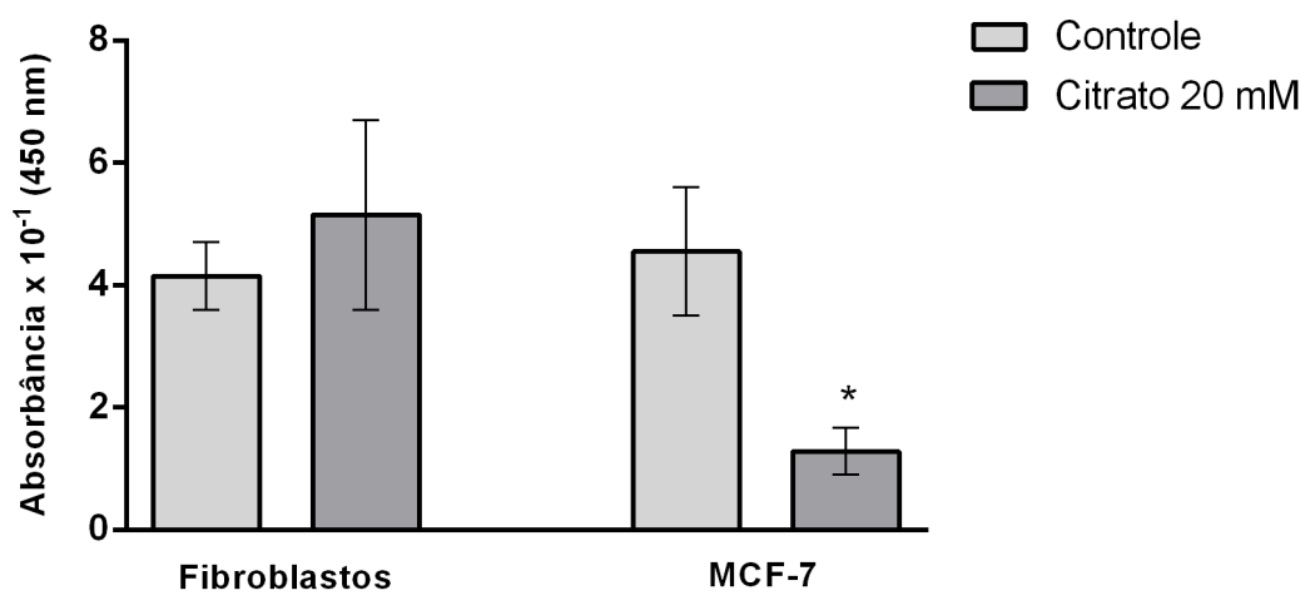

Figura 14. Atividade da enzima fosfofrutoquinase. Ensaio realizado com o reagente PFK Colorimetric Assay Kit mostrou redução $\left({ }^{*} p<0,05\right)$ da atividade da enzima fosfofrutoquinase em células MCF-7 após tratamento com citrato $20 \mathrm{mM}$.

\subsection{Teor de lactato em MCF-7}

Os níveis intracelulares de lactato (Figura 15) foram significativamente aumentados em células MCF-7 após $24 \mathrm{~h}$ de tratamento com citrato $20 \mathrm{mM}(22,78 \pm$ $0,01 \mathrm{ng} / \mu \mathrm{L})$ em relação ao teor presente na amostra controle $(10,09 \pm 0,26 \mathrm{ng} / \mu \mathrm{L})$.

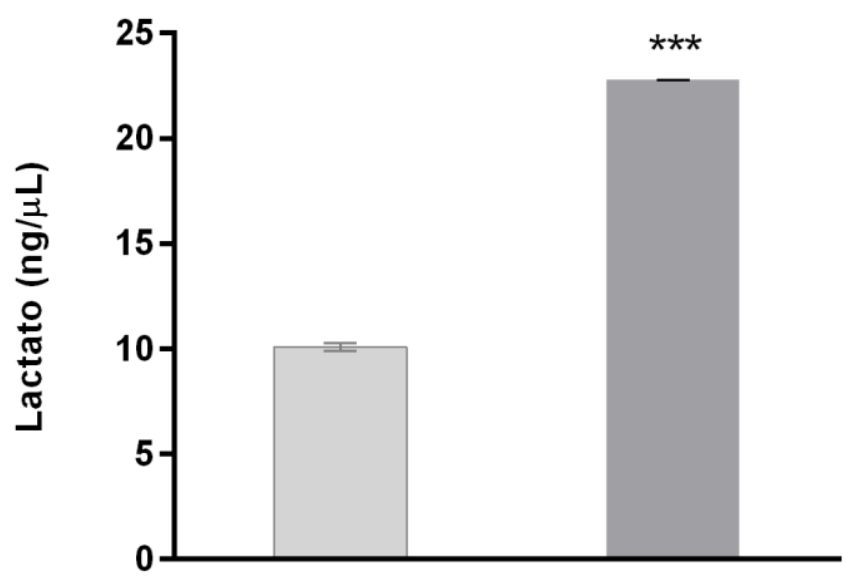

Controle

Citrato $20 \mathrm{mM}$

Figura 15. Teor de lactato em MCF-7. Células sem tratamento e tratadas com citrato $20 \mathrm{mM}$ por 24 $\mathrm{h}$ foram avaliados quanto ao teor de lactato intracelular utilizando o reagente Lactate Assay Kit. ${ }^{* \star *}$ representa diferença estatisticamente significativa $(p<0,001)$. 


\subsection{Espécies reativas de oxigênio}

Fibroblastos (A) e células MCF-7 (B) foram avaliados quanto à formação de ERO (figura 16) após tratamento com citrato $20 \mathrm{mM}$ por $24 \mathrm{~h}$, utilizando o marcador DCFH-DA. Houve diferença estatisticamente significativa $(p<0,05)$ entre os tratamentos (0 e $20 \mathrm{mM}$ ) em MCF-7.

\section{$0 \mathrm{mM}$}

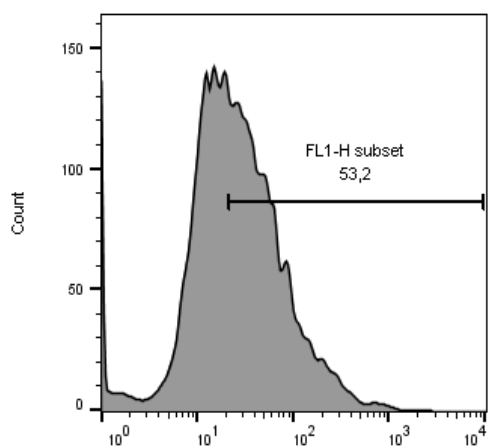

FL1-H

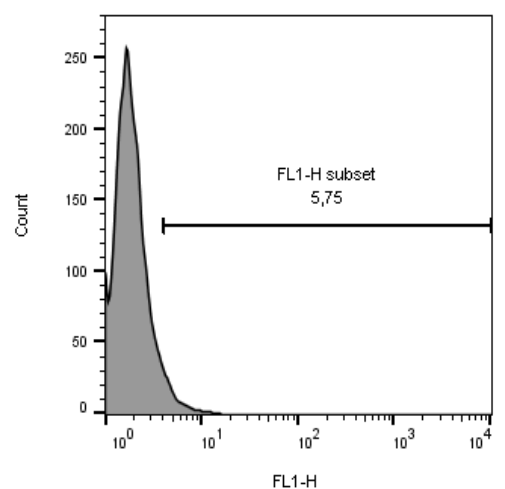

Citrato $20 \mathrm{mM}$

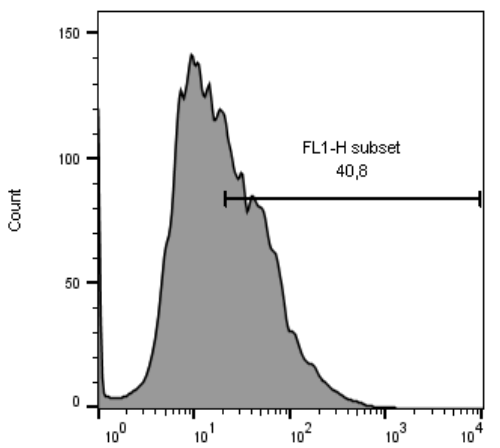

FL1-H

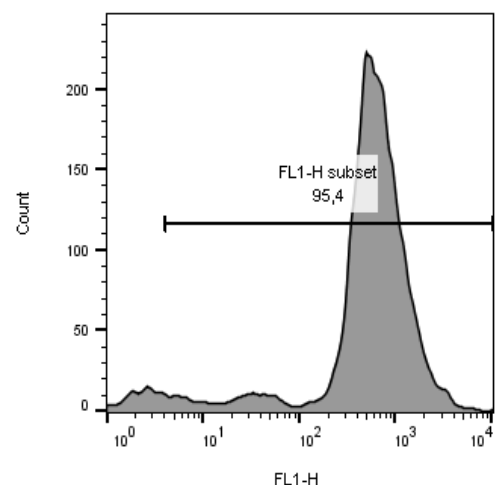

$\mathrm{H}_{2} \mathrm{O}_{2}$

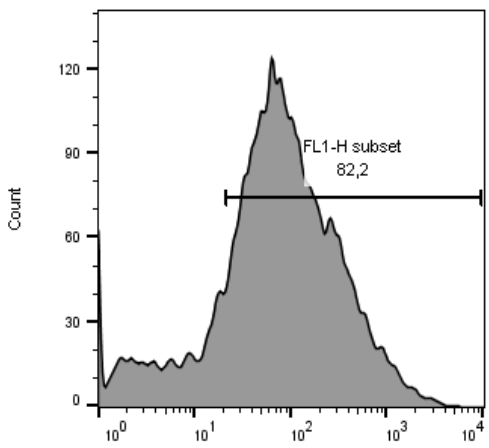

FL1-H

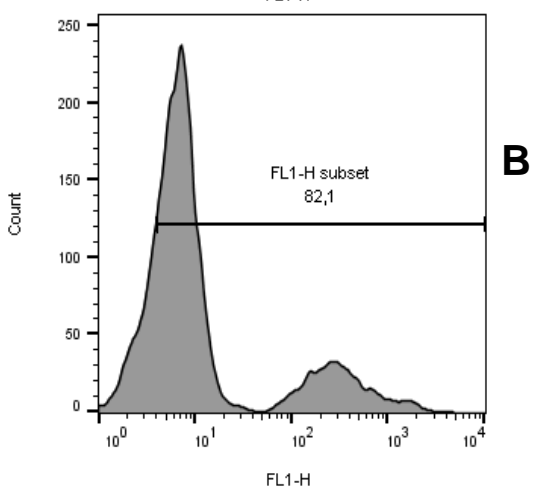

Figura 16. Produção de espécies reativas de oxigênio. Fibroblastos (A) e células MCF-7 (B) foram avaliados quanto à produção de espécies reativas de oxigênio - ERO utilizando o marcador DCFH-DA. Peróxido de hidrogênio $200 \mu \mathrm{M}$ foi utilizado como controle positivo. Houve diferença estatisticamente significativa na produção de ERO entre células MCF-7 tratadas e controle.

\subsection{Potencial de membrana mitocondrial}

Utilizando a sonda fluorescente Rodamina-123, foi observado que amostras controle $(0 \mathrm{mM})$ e tratadas com citrato $20 \mathrm{mM}$ por $24 \mathrm{~h}$ e paclitaxel por $6 \mathrm{~h}$ (controle positivo) não apresentaram alteração do potencial de membrana mitocondrial (Figura 17) estatisticamente significativa $(p>0,05)$. No entanto, no desenvolvimento do 
ensaio houve perda de células dos grupos experimentais, o que impossibilitou a avaliação de 10.000 eventos por amostra.

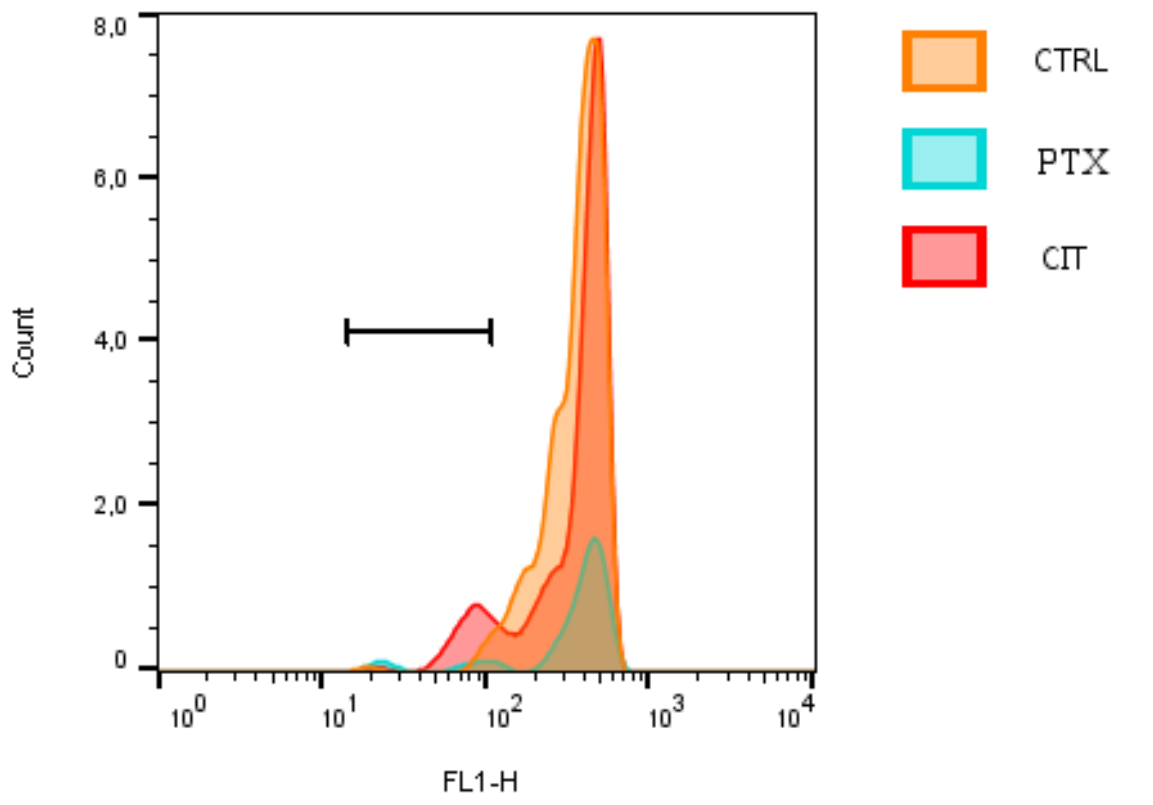

A

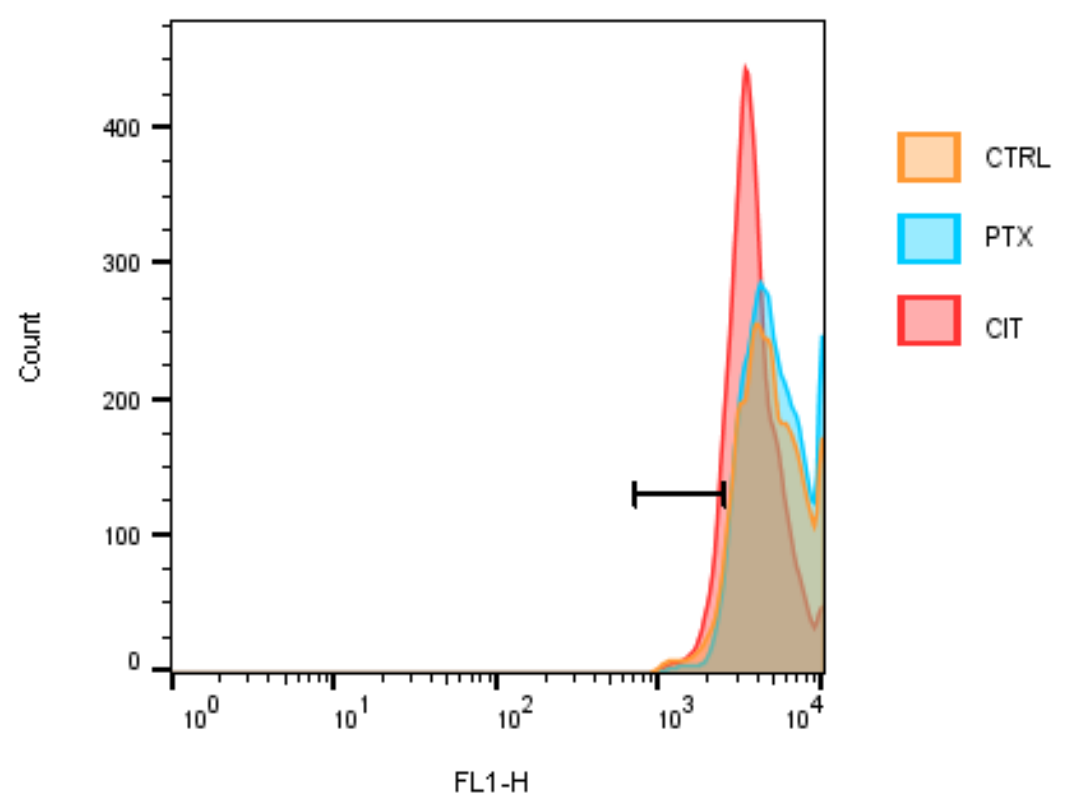

B

Figura 17. Potencial de membrana mitocondrial. Amostras de fibroblastos (A) e células MCF-7 (B) sem tratamento (CTRL) e tratados com citrato (CIT) $20 \mathrm{mM}$ e Paclitaxel (PTX) $50 \mu \mathrm{M}$ (controle positivo) foram avaliados quanto a alterações no potencial de membrana utilizando o marcador Rodamina-123. Não houve diferença estatisticamente significativa $(p>0,05)$. 


\section{DISCUSSÃO}

Entre as diferentes marcas já identificadas que caracterizam o câncer, este trabalho se concentrou na reprogramação do metabolismo energético. Considerando que as células de câncer apresentam intensa atividade glicolítica para produção de energia, um tratamento antineoplásico baseado em citrato apresenta como estratégia a utilização da própria maquinaria enzimática da célula para gerar estresse metabólico.

Para sobreviver e proliferar, as células neoplásicas, assim como as células normais, necessitam de oferta de nutrientes e de oxigênio. Nesse sentido, a indução da angiogênese no tumor é fundamental para sustentar o crescimento e a proliferação celular desregulada (FOLKMAN, 2006). Mitógenos como o VEGF, fator de crescimento endotelial vascular, são hiperexpressos em cânceres, o que pode estar relacionado a oncogenes ativados, liberação de fatores de crescimento e hipóxia (CARMELIET, 2005). No entanto, o tumor apresenta má formação dos vasos sanguíneos, assim como a vascularização não é uniforme (BALUK et al, 2005; NAGY et al, 2010). A deficiência na irrigação do tumor resulta em área central necrótica, enquanto as células da periferia, vascularizadas, mantêm a proliferação (HOLASH et al, 1999).

Os baixos níveis de oxigênio observados no microambiente dos tumores (BERTOUT, 2008) podem favorecer um tratamento baseado em citrato. Inibindo a glicólise, via enzima fosfofrutoquinase (SCHIRMER, 1990), a obtenção de energia pela fosforilação oxidativa também estaria prejudicada pela deficiência no suprimento de oxigênio molecular, que é o aceptor final de elétrons (WILSON et al, 1979). Assim, alteração na razão de NADH, que carreia os elétrons para o complexo I da cadeia transportadora de elétrons, e $\mathrm{NAD}^{+}$causaria perturbação no equilíbrio redox, podendo gerar espécies reativas de oxigênio (TRETTER \& ADAM-VIZI, 2004).

A produção de ATP pela fosforilação oxidativa requer a oxidação completa da glicose no cliclo do ácido tricarboxílico, reduzindo os carreadores de elétrons $\mathrm{NAD}^{+}$a NADH e FAD ${ }^{+}$a FADH ${ }_{2}$ e formando $\mathrm{CO}_{2}$ como subproduto (LEHNINGER et al, 2011). No entanto, no metabolismo reprogramado das células de câncer, a glicólise gera o aporte energético, enquanto metabólitos intermediários da via glicolítica e do ciclo de Krebs fornecem os precursores anabólicos para a biossíntese 
das macromoléculas requeridas para a proliferação celular (CAIRNS, 2015). Com isto, a interrupção da via glicolítica das células de câncer por inibição da enzima fosfofrutoquinase, ocasionada pelo tratamento com citrato, e a conversão desta molécula para o anabolismo dos ácidos graxos promoveriam a depleção do ATP necessário para a proliferação. Considerando a ocorrência de citotoxicidade induzida por tratamento com citrato demonstrada pelo método colorimétrico MTT, sugere-se que a inviabilidade celular pode ter sido causada por esta deficiência, a qual pode favorecer a inibição das bombas de efluxos de fármacos dependentes de ATP. A inibição reduz a resistência do tumor a tratamentos com quimioterápicos, cuja acumulação intracelular é diminuída pelas bombas (MA et al, 2015; ZHENG et al, 2016). Isto favorece uma terapia combinada com citrato.

Os testes realizados para avaliar a captação extracelular de citrato mostraram que o nível intracelular da molécula é elevado nos grupos controles de células MCF-7 quando comparado com os de fibroblastos. No entanto, após 24 h de exposição ao tratamento, fibroblastos apresentaram quantidades de citrato similares à MCF-7. Isto indica que, proporcionalmente, as células tumorais metabolizaram a molécula mais rapidamente do que as células normais. A enzima ATP citrato liase, que converte citrato a acetil-CoA no citoplasma, é hiperativada em células de câncer (CHEN et al, 2016), assim como a enzima ácido graxo sintase (VAZQUEZ-MARTIN et al, 2008). Desse modo, o citrato pode estar sendo metabolizado para a lipogênese de novo. Volinksy e colaboradores (2015) observaram que o fenótipo lipogênico em células de câncer é regulado pela sinalização PI3K-mTORC1 mais do que da absorção extracelular de ácidos graxos.

Foi verificado que a síntese de novo do ácido graxo palmitato em células de câncer, decorrente da superexpressão de ACLy e da ácido graxo sintase, pode ativar receptores do fator de crescimento epidermal mitocondrial e promover a fusão mitocondrial (BOLLU et al, 2014). Fissão e fusão das mitocôndrias são processos que regulam a função da organela e a sinalização retrógrada (BERNARD \& ROSSIGNOL, 2008). Esta dinâmica é contínua e é resposta a estresses ambientais e celulares. A elongação das mitocôndrias tem como consequência o aumento da capacidade oxidativa e a redução na produção de espécies reativas de oxigênio, da transição de permeabilidade, da mitofagia e de morte celular, enquanto a fragmentação tem efeito contrário (PICARD, 2013). Considerando que não foram constatadas alterações ultraestruturais das mitocôndrias de MCF-7 no que se refere 
aos parâmetros morfométricos analisados, infere-se que estas células tumorais não foram capazes de responder às alterações metabólicas produzidas por citrato, resultando em maior redução da viabilidade celular quando comparadas com fibroblastos.

A alteração na área mitocondrial média observada em fibroblastos tratados com citrato está compatível com os resultados obtidos por citometria de fluxo, que não mostraram alterações significativas na produção de ERO em comparação com o grupo controle. As células tumorais MCF-7, no entanto, foram mais susceptíveis ao estresse. As células de câncer, embora caracterizadas pelo crescimento celular desregulado, necessitam de um estado homeostático para existir como célula viável (ZHANG et al, 2015).

O estresse oxidativo provocado por ERO produz alterações na permeabilidade da membrana mitocondrial e na sua estrutura de forma reversível (NELSON et al, 2010). É importante destacar que a membrana mitocondrial externa é permeável ao citrato, mas a passagem pela membrana interna é mediada por proteína transportadora (PALMIERI, 2010). A perda de potencial de membrana mitocondrial, no entanto, é um processo que induz a célula à apoptose (SINGH et al, 2011). No ensaio realizado neste trabalho verificamos que o $\Delta \Psi$ das células normais e tumorais não foi alterado significativamente pela ação do citrato. A manutenção do $\Delta \Psi$ verificada em ambas as células após tratamento indica que a produção de ATP pela fosforilação oxidativa estaria preservada. No entanto, a possível depleção de ATP ocasionada pelo estresse metabólico produzido pelo excesso de citrato pode ter superado a capacidade da célula em manter a sua homeostase, levando-a a morte.

O tratamento com citrato foi capaz de reduzir a atividade da enzima fosfofrutoquinase em células MCF-7, o que afeta a produção de ATP pela via glicolítica. No entanto, o conteúdo de lactato nas células tumorais foi elevado. Este resultado sugere que a glicólise pode ter sido apenas parcialmente inibida, ocorrendo, então, fermentação dirigida para produção de lactato a partir de piruvato. Outra resposta seria que o lactato está sendo formado devido à metabolização do citrato extracelular. A reação catalisada pela enzima ACLy também converte citrato a oxaloacetato (SRERE \& LIPMANN, 1953), que pode restaurar piruvato (WILKINS et al, 2016). 
A molécula lactato produzida em elevados níveis por células dependentes de glicólise para produção de ATP, tais como as células de câncer, é exportada para o ambiente extracelular por meio do transportador de monocarboxilatos MCT4 (ULLAH et al, 2006; VAZ et al, 2016). Células de câncer interagem com o microambiente do tumor por meio de sinalização extracelular. O efluxo de lactato promove uma resposta local anti-inflamatória, recrutando células imunes que secretam fatores de crescimento e citocinas. Estas moléculas favorecem a proliferação celular e a mestástase (SHIME et al, 2008). Inibidores da enzima LDH-A pode limitar a sinalização para a angiogênese (ZHOU, 2010) e favorecer o tratamento combinado com citrato. Ainda, foi constatado que a enzima lactato deidrogenase B (LDH-B), que converte lactato a piruvato, é silenciada em células de câncer de mama (BROWN et al, 2009). Thangaraju e colaboradores (2009) observaram que piruvato inibe histonas deacetilases que silenciam a LDH-B e que os níveis de piruvato em células de câncer de cólon são muito mais baixos que os de células de cólon não tumorais. No ensaio realizado com o reagente Citrate Assay Kit, verificamos que MCF-7 possuem teor de piruvato mais elevado que fibroblastos e que a concentração do metabólito no controle branco de MCF-7 aumentou após tratamento com citrato.

Os resultados obtidos neste trabalho sugerem que a redução na viabilidade das células tumorais foi favorecida pela inibição da glicólise via enzima fosfofrutoquinase e pelo uso da maquinaria enzimática para metabolizar o citrato extracelular, ocasionando depleção de ATP pelo anabolismo dos ácidos graxos. Além disso, não foram observadas alterações na dinâmica mitocondrial como resposta ao estresse metabólico causado pelo tratamento.

O efeito sinérgico do potencial citotóxico do citrato associado a outros materiais também vem sendo explorado (ZHANG, 2009). Além disso, o emprego de nanotecnologia pode viabilizar a ação seletiva do tratamento, reduzindo os efeitos adversos (COLOMBO, 2012). A nanotecnologia possibilita uma abordagem multidisciplinar empregada na engenharia de sistemas nanoestruturados como veículos de entrega de agentes antitumorais em células de câncer, favorecendo o potencial terapêutico (COUVREUR \& VAUTHIER, 2006; MAHAPATRO \& SINGH, 2011). Assim, formulações com citrato em sua composição e que permita sua liberação no tecido alvo podem representar promissora aplicação terapêutica para câncer de mama. 


\section{CONCLUSÕES}

Baseado nos resultados obtidos nesse trabalho, concluímos que:

- No tempo de 24 h, o tratamento com citrato na concentração de $20 \mathrm{mM}$ foi mais citotóxico em células MCF-7 do que em fibroblastos.

- O conteúdo de citrato intracelular é elevado em células MCF-7 em comparação com fibroblastos. As células tumorais também metabolizaram o citrato mais rapidamente do que células normais.

- Houve redução na atividade da enzima fosfotrutoquinase em células MCF-7 tratadas. No entanto, o conteúdo de lactato nesta linhagem aumentou com o tratamento com citrato.

- Fibroblastos apresentaram alterações na dinâmica mitocondrial em resposta ao tratamento. A elongação pode ter protegido a organela do estresse oxidativo induzido pelo citrato, enquanto células MCF-7 foram mais susceptíveis à formação de espécies reativas de oxigênio. 


\section{PERSPECTIVAS}

Outros ensaios serão realizados para averiguar ocorrência de depleção de ATP, síntese de ácidos graxos e alterações em outros parâmetros morfométricos da mitocôndria que possam explicar os mecanismos pelos quais o citrato produz efeito citotóxico nas células tumorais.

Novos estudos serão conduzidos para investigar o potencial antitumoral da combinação do citrato com formulações nanoestruturadas. 


\section{REFERÊNCIASBIBLIOGRÁFICAS}

ALBERTS, B. et al. Molecular biology of the cell. $5^{\text {th }}$ ed. New York: Garland, 2008. $1268 \mathrm{p}$.

AMERICAN CANCER SOCIETY - ACS. Breast Cancer Prevention and Early Detection. Atlanta: American Cancer Society, 2015. 23p. Disponível em: <http://www.cancer.org/acs/groups/cid/documents/webcontent/003165-pdf.pdf>. Acesso em: 27 jan. 2016.

BALUK, P.; HASHIZUME, H; MCDONALD, D. M. Cellular abnormalities of blood vessels as targets in cancer. Curr Opin Genet Dev, v. 15, p. 102-111, 2005.

BARACCA, A. et al. Rhodamine 123 as a probe of mitochondrial membrane potential: evaluation of proton flux through F0 during ATP synthesis. Biochim Biophys Acta, v. 1606, p.137-146, 2003.

BASS, D. A. et al. Flow cytometric studies of oxidative product formation by neutrophils: a graded response to membrane stimulation. $J$ Immunol, v. 130, n. 4, p. 1910-1917, 1983.

BERG, K. et al. A new sensitive bioassay for precise quantification of interferon activity as measured via the mitochondrial dehydrogenase function in cells (MTTmethod). APMIS, v. 98, p. 156-162, 1990.

BERNARD, G.; ROSSIGNOL, R. Ultraestructure of the mitochondrion and its bearing on function and bioenergetics, Antioxid Redox Signal, v. 10, n. 8, p. 1313-1342, 2008.

BERTOUT, J.A.; PATEL, S. A.; SIMON, M. C. The impact of $\mathrm{O}_{2}$ availabilty on human cancer. Nature Rev, v. 8, p. 967-975, 2008.

BOLLU, L. R. et al. Involvement of de novo synthesized palmitate and mitochondrial EGFR in EGF induced mitochondrial fusion of cancer cells. Cell Cycle, v. 13, n. 15, p. 2415-2430, 2014.

BROWN, N. J. et al. Lactate dehydrogenase-B is silenced by promoter methylation in a high frequency of human breast cancer. PloS One, v. 8(2): e57697, 8p, 2013.

BUCAY, H. A. Clinical report: A patient with primary peritoneal mesothelioma that has improved after taking citric acid orally. Clin Res Hepatol Gastroenterol, v. 35, p. 241, 2011.

. Hypothesis proved... citric acid (citrate) does improve cancer: a case of a

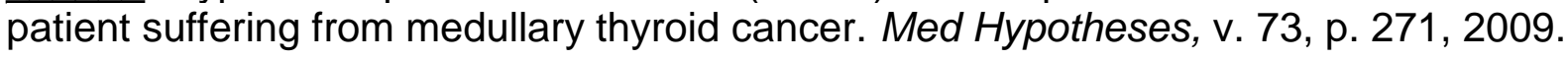

CAIRNS, R. A. Drivers of the Warburg phenotype. Cancer J, v. 21, n. 2, p. 56-61, 2015. 
CALABRESE, C. et al. Respiratory complex I is essential to induce a Warburg profile in mitochondria-defective tumor cells. Cancer Metab, v. 1, 15p, 2013.

CARMELIET, P. VEGF as a key mediator of angiogenesis in cancer. Oncology, v. 69 (suppl3), p. 4-10, 2005.

CATALINA-RODRIGUEZ, O. C. et al. The mitochondrial citrate transporter, CIC, is essential for mitochondrial homeostasis. Oncotarget, v. 3, n. 10, p. 1220-1235, 2012.

CHEN, Y. et al. mTOR complex-2 stimulates acetyl-CoA and de novo lipogenesis through ATP citrate lyase in HER2/PIK3CA-hyperactive breast cancer. Oncotarget, v. 7, n. 18, p. 25224-25240, 2016.

CHENG, S. et al. Distinct metabolomics signatures are associated with longevity in humans. Nat Commun, doi:10.1038/ncomms7791, 22p, 2015.

COLOMBO, M. et al. Biological applications of magnetic nanoparticles. Chem Soc Rev, v. 41, p. 4306-4334, 2012.

COUVREUR, P.; VAUTHIER, C. Nanotechnology: intelligent design to treat complex disease. Pharm Res, v. 23, n. 7, p. 1417-1450, 2006.

FADOK, V. A. et al. Exposure of phosphatidylserine on the surface of apoptotic lymphocytes triggers specific recognition and removal by macrophages. J Immunol, v. 148, n. 7, p. 2207-2216, 1992.

FOLKMAN, J. Angiogenesis. Ann Rev Med, v. 57, p. 1-18, 2006.

GALLUZZI, L. et al. Metabolic targets for cancer therapy. Nat Rev Drug Discov, v.12, p. 829-846, 2013.

GOMEZ, L. S. et al. Resveratrol decreases breast cancer cell viability and glucose metabolism by inhibiting 6-phosphofructo-1-kinase. Biochimie, n. 95, p. 1336-1343, 2013.

GRIGORIEFF, N. Structure of the respiratory NADH: ubiquinone oxidoreductase (complex I). Curr Opin Struct Biol, v. 9, p. 476-843, 1999.

GÜNTHER, U. L. Metabolomics biomarkers for breast cancer. Pathobiology, v. 82, p. 153-165, 2015.

HANAHAN, D.; WEINBERG, R. A. Hallmarks of cancer: The next generation. Cell, v.144, n. 5, p.646-674, 2011.

HOLASH, J.; WIEGAND, S. J.; YANCOPOULOS, G. D. New model of tumor angiogenesis: dynamic balance between vessel regression and growth mediated by angiopoietins and VEGF. Oncogene, v. 18, p. 5356-5362, 1999.

IACOBAZZI, V.; INFANTINO, V. Citrate - new functions for an old metabolite. Biol Chem, v. 395, n. 4, p. 387-399, 2014. 
INSTITUTO BRASILEIRO DE GEOGRAFIA E ESTATÍSTICA - IBGE. Pesquisa Nacional por Amostra de Domicílios: Um panorama de saúde no Brasil: acesso e utilização dos serviços, condições de saúde e fatores de risco e proteção à saúde 2008. Rio de Janeiro: IBGE, 2010. 245p. Disponível em:

<http://biblioteca.ibge.gov.br/visualizacao/monografias/GEBIS\%20-

\%20RJ/panorama.pdf >. Acesso em: 27 jan. 2016.

INSTITUTO NACIONAL DE CÂNCER - INCA (Brasil). Estimativa 2016: incidência de Câncer no Brasil. Rio de Janeiro: INCA, 2016. 126p. Disponível em:

<http://www.inca.gov.br/estimativa/2016/estimativa-2016-v11.pdf>. Acesso em: 08 mar. 2016.

Atlas On-line de Mortalidade. Rio de Janeiro: INCA, 2014. Disponível em: <https://mortalidade.inca.gov.br/MortalidadeWeb/> Acesso em: 27 jan. 2016.

. Controle do Câncer de Mama: Documento do Consenso. Rio de Janeiro: INCA, 2004. 39p. Disponível em:

<http://www1.inca.gov.br/publicacoes/Consensointegra.pdf>. Acesso em: 27 jan. 2016.

JENEY, A. et al. Characterization of bioenergetics pathways and related regulators by multiple assays in human tumor cells. Cancer Cell Int, v. 16, n. 4, 10p, 2016.

JIANG, X.; ELLIOT, R. L.; HEAD, J. F. Exogenous normal mammary epithelial mitochondria suppress glycolytic metabolism and glucose uptake of human breast cancer cells. Breast Cancer Res Treat, v. 153, p. 519-529, 2015.

KERR, J. F.; WYLLIE, A. H.; CURIE, A. R. Apoptosis: a basic biological phenomena with wide-hanging implications in tissue kinetics. Br J Cancer, v. 26, p. 239-257, 1972.

KISHTON, R. J.; RATHMELL, J. C. Novel therapeutic targets of tumor metabolism. Cancer J, v. 21, n. 2, p. 62-69, 2015.

KLUCK, R. M. et al. The release of cytochrome $\mathrm{c}$ from mitochondria: a primary site for bcl-2 regulation of apoptosis. Science, v. 275, p. 1132-1136, 1997.

KRANZ, L. M. et al. Systemic RNA delivery to dendritic cells exploits antiviral defense for cancer immunotherapy. Nature, v. 534, n. 7607, p. 396-401, 2016.

KREBS, H. A. The citric acid cycle. Biochem J, v. 32, n. 1, p. 460-463, 1940.

KREBS, H. A.; SALVIN, E.; JOHNSON, W. A. The formation of citric and $\alpha-$ ketoglutaric acids in the mammalian body. Biochem J, v. 32, n. 1, p. 113-117, 1938. KRUSPIG, B. Citrate kills tumor cells through activation of apical caspases. Cell Mol Life Sci, v. 69, p. 4229-4237, 2012.

LAKHANI, S. et al. WHO Classification of tumor of the breast. Lyon: IARC, 2012. 
LEHNINGER, A. L.; NELSON, D. L.; COX, M. M. Princípios de bioquímica de Lehninger. 5 ed. Porto Alegre: Artmed, 2011. 1273p.

LINCET, H. et al. Inhibition of Mcl-1 expresion by citrate enhances the effect of Bcl-xL inhibitors on human ovarian carcinoma cells. J Ovarian Res, v. 6, n. 72, 10p, 2013.

LIU, X. et al. Induction of apoptotic program in cell-free extracts: requirement for dATP and cytochrome c. Cell, v. 86, p. 147-157, 1996.

LU, Y et al. Citrate induces apoptotic cell death: a promising way to treat gastric carcinoma? Anticancer Res, v.31, p. 797-806, 2011.

MA, S. et al. Targeting cellular metabolism chemosensitizes the doxorubicin-resistant human breast adenocarcinoma cells. Biomed Res Int, v. 2015, 8p.

MA, Y. et al. Mitochondrial dysfunction promotes breast cancer cell migration and invasion through HIF1 a accumulation via increased production of reactive oxygen species. Plos One, v. 8, n. 7, 10p, 2013.

MAGDALENA, A. C. et al. Microenvironmental influences that drive progression from benign breast disease to invasive breast cancer. J Mammary Gland Biol Neoplasia, v. 15, p. 389-397, 2010.

MAHAPATRO, A; SINGH, K. Biodegradable nanoparticles are excellent vehicle for site directed in-vivo delivery of drugs and vaccines. J Nanobiotechnology, v. 9, n. 55, $11 p, 2011$.

MELERO, I. et al. Therapeutic vaccines for cancer: an overview of clinical trials. Nat Rev Clin Oncol, v. 11, n. 9, p. 509-524, 2014.

NAGY, J. A. et al. Heterogeneity of the tumor vasculature. Semin Thromb Hemost, v. 36, p. 321-331, 2010.

NEWSHOLME, E. A.; SUGDEN, P. H.; WILLIAMS, T. Effect of citrate on the activities of 6-phosphofructokinase from nervous and muscle tissues from different animals and its relationships to the regulation of glycolysis. Biochem J, v. 166, p.123-129, 1977.

NEWSHOLME, E. A. The role of the fructose 6-phosphate/fructose 1,6-diphosphate cycle in metabolic regulation and heat generation. Biochem Soc Trans, v. 4, n. 6, p. 978-984, 1976.

NELSON, B. C. et al. Oxidative stress causes reversible changes in mitochondrial permeability and structure. Exp Gerontol, v. 45, p. 596-602, 2010.

OZKAYA, A. B. et al. Targeting mitochondrial citrate transport in breast cancer cell lines. Anticancer Agents Med Chem, v. 15, n. 3, p. 374-381, 2015. 
PALMA, A. et al. Metabolic study of breast MCF-7 tumor spheroids after gamma irradiation by H NMR spectroscopy and microimaging. Front Oncol, v. 6, n. 105, 9p, 2016.

PALMIERI, F.; PIERRI, C. L. Mitochondrial metabolite transport. Essays Biochem, v. 47, p. 37-52, 2010.

PICARD, M. et al. Mitochondrial morphology transitions and functions: implications for retrograde signaling? Am J Physiol Regul Integr Comp Physiol, v. 304, p. 393406, 2013.

PORPORATO, P. E. et al. Anticancer targets in the glycolytic metabolism of tumors: a comprehensive review. Front Pharmacol, v. 2, 18p, 2011.

ROGERS, S. et al. Identification of a novel glucose transporter-like protein - GLUT12. Am J Physiol Endocrinol Metab, v. 283, p. 733-738, 2002.

SCHIRMER, T.; EVANS, P.R. Structural basis of the allosteric behavior of phosphofructokinase. Nature, v. 343, p. 140-145, 1990.

SCHULER, M. et al. Activation through mitochondrial p53 induces apoptosis by caspase cytochrome c release. J Biol Chem, v. 275, p. 7337-7342, 2000.

SINN, H.; KREIPE, H.A brief overview of the WHO classification of the breast tumor, 4th edition, focusing on issues and updates from the 3rd edition. Breast Care, v. 8, p. 149-154, 2013.

SINGH, T.; SHARMA, S. D.; KATIYAR, S. K. Grape proanthocyanidins induce apoptosis by loss of mitochondrial membrane potential of human non-small cell lung cancer cells in vitro and in vivo. Plos One, v. 6, e27444, 2011.

SHARMA, L. K. et al. Mitochondrial respiratory complex I dysfunction promotes tumorigenesis through ROS alteration and AKT activation. Hum Mol Genet, v. 20, n. 23, p. 4605-4616, 2011.

SHIME H. et al. Tumor-secreted lactic acid promotes IL-23/IL-17 proinflammatory pathway. J Immunol, v. 180, n. 11, p.7175-7183, 2008.

SOULE, H. D. et al. A human cell line from a pleural effusion derived from a breast carcinoma. J Natl Cancer Inst, v 51, n. 5, p. 1409-1416, 1973.

SRERE, P. A.; LIPMANN, F. An enzymatic reaction between citrate, adenosine triphosphate and coenzyme A. J Am Chem Soc, v. 75, p. 4874, 1953.

SRINIVASAN, S. et al. Disruption of cytochrome c oxidase function induces the Warburg effect and metabolic reprogramming. Oncogene, v. 35, n. 12, p. 1585-1595, 2016. 
SUN, J. et al. Mitochondrial and Plasma Membrane Citrate Transporters: Discovery of Selective Inhibitors and Application to Structure/Function Analysis. Mol Cell Pharmacol, v. 2, n.3 p. 101-110, 2010.

THANGARAJU, M. et al. Colon cancer cells maintain low levels of pyruvate to avoid cell death caused by inhibition of HDAC1/HDAC3. Biochem J, v. 417, p. 379-389, 2009.

TRETTER, L.; ADAM-VIZI, V. Generation of reactive oxygen species in the reaction catalyzed by alpha-ketoglutarate dehydrogenase. J Neurosci, v. 24, p. 7771-7777, 2004.

ULLAH, M. S; DAVIES, A. J.; HALESTRAP, P. A. The plasma membrane lactate transporter MCT4, but not MCT1, is up-regulated by hypoxia through a HIF-1dependent mechanism. J Biol Chem, v. 281, n. 14, p. 9030-9037, 2006.

VANDER HEIDEN, M. G.; CANTLEY, L. C.; THOMPSON, C. B. Understanding the Warburg effect: the metabolic requirements of cell proliferation. Science, v. 324, n. 5930, p. 1029-1033, 2009.

VAZ, C. V. et al. Androgens enhance the glycolytic metabolism and lactate export in prostate cancer cells by modulating the expression of GLUT1, GLUT3, PFK, LDH and MCT4 genes. J Cancer Res Clin Oncol, v. 142, p. 5-116, 2016.

VAZQUEZ-MARTIN, A. et al. Overexpression of fatty acid synthase gene activates HER1/HER2 tyrosine kinase receptors in human breast epithelial cells. Cell Prolif, v. 41, n.1, p. 59-85, 2008.

VOLINSKY, N. et al. Signalling mechanisms regulating phenotypic changes in breast cancer cells. Biosci Rep, v. 35, 14p, 2015.

WARBURG, O. On the origin of cancer cells. Science. v. 123, n. 3191, p. 309-314, 1956.

WARBURG, O.; WIND, F.; NEGELEIN, E. The metabolism of tumors in the body. The J Gen Physiol, v. 8, n. 6, p. 519-530, 1927.

WILKINS, H. M. et al. Oxaloacetate enhances neuronal cel bionergetic fluxes and infrastructure. J Neurochem, v. 137, n. 1, p. 76-87, 2016.

WILSON, D. F.; OWEN, C. S.; ERECIŃSKA, M. Quantitative dependence of mitochondrial oxidative phosphorilation on oxygen concentration: a mathematical model. Arch Biochem Biophys, v. 195, n. 2, p. 494-504, 1979.

WORLD HEALTH ORGANIZATION - WHO. International Agency for Research on Cancer. Globocan 2012. Iarc, 2016. Disponível em:

<http://globocan.iarc.fr/Pages/burden_sel.aspx>. Acesso em: 23 jul. 2016. 
Cancer Control. Knowledge into action. WHO guide for effective pogrammes. Diagnosis and Treatment Module. Switzerland: WHO, 2008. 50p. Disponível em: <http://www.who.int/cancer/modules/FINAL_Module_4.pdf>. Acesso em: 27 jan. 2016.

ZHANG, S. et al. Homeostasis of redox status derived from glucose metabolic pathway could be the key to understanding the Warburg effect. Am J Cancer Res, v. 5, n. 4, p. 1265-1280, 2015.

ZHANG, X. et al. Effect of citrate on malignant pleural mesothelioma cells: a synergistic effect with cisplatin. Anticancer Res, v. 29, p. 1249-1254, 2009.

ZHAO, Y. et al. Overcoming Trastuzumab resistance in breast cancer by targeting dysregulated glucose metabolism. Cancer Res. v. 71, p. 4585-4597, 2011.

ZHENG, W. et al. Altered glucose metabolism in Harvey-ras transformed MCF10A cells. Mol Carcinog, doi: 10.1002/mc.22079, 10p, 2013.

ZHENG, X. et al. Targeting multidrug-resistant ovarian cancer through estrogen receptor a dependent ATP depletion caused by hyperactivation of the unfolded protein response. Oncotarget, doi: 10.18632/oncotarget.10819, 13p, 2016.

ZHOU, M. et al, Warburg effect in chemosensitivity: targeting lactate dehydrogenaseA re-sensitize taxol-resistant cancercells to taxol. Mol Cancer, doi:10.1186/14764598-9-33, v. 9, n. 33, 2010.

ZHOU, X. et al. Dichloroacetate restores drug sensitivity in paclitaxel-resistant cells by inducing citric acid accumulation. Mol Cancer, v. 14, n. 63, 12p, 2015.

ZONG, W. X.; RABINOWITZ, J. D.; WHITE, E. Mitochondria and cancer. Mol Cell, v. 61, n. 5, p. 667-676, 2016.

ZOU, H. Apaf-1, a human protein homologous to C. elegans CED-4, participates in cytochrome c-dependent activation of caspase-3. Cell, v. 90, p. 405-413, 1997. 